\title{
جودة المياة الأسرية وتنمية القدرات الإبداعية للأبناء
}

إعد (د)

أ.د/ أماني عبد المقصود عبد الوهاب

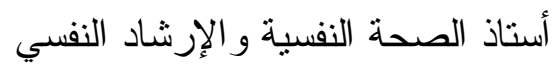

ووكيل كلية التربية النوعية-جامعة المنوفية

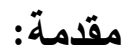

تمثل الأسرة الركيزة الأساسية فى تخطيط وبناء شخصية الأبناء من خلال الرعاية

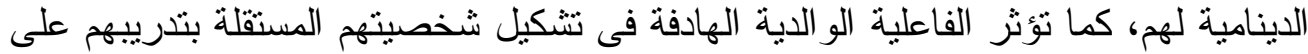

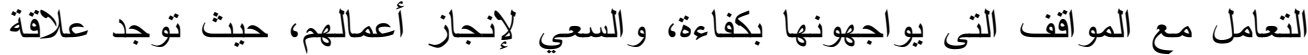

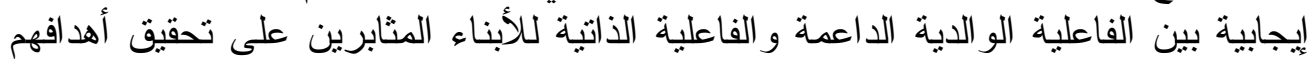

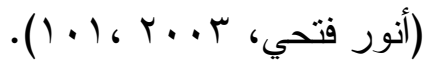

وبما أن الأسرة هى الجماعة الأولية النى يعيش فيها الطفل، فإن للأسرة التأثير الأكبر

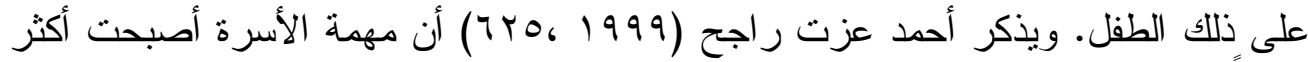

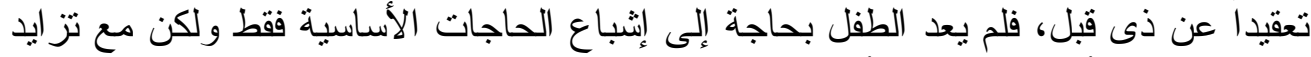

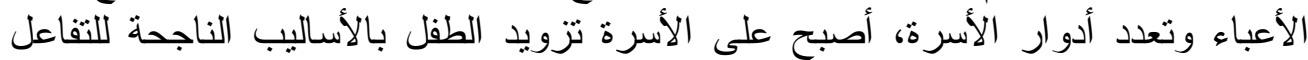
و التكيف مع الحياة.

إن نربية الإبداع عملية نسير وفق نمو الطفل ووفق إثباع حاجاته الأساسية

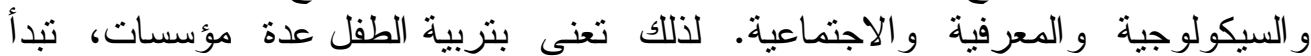

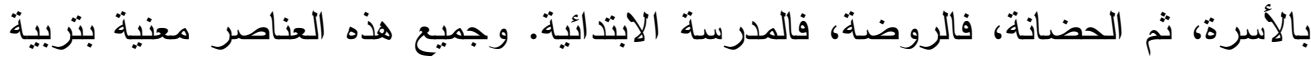

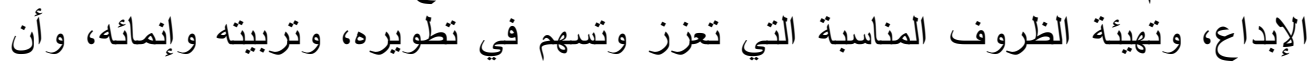

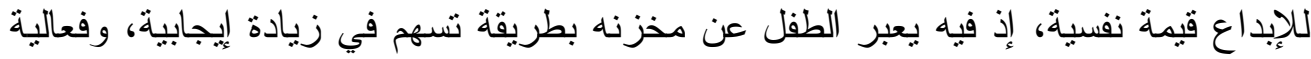

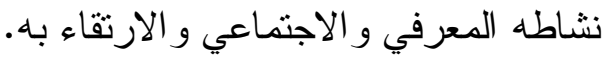

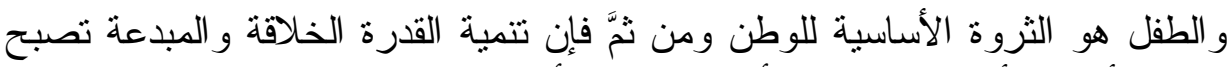

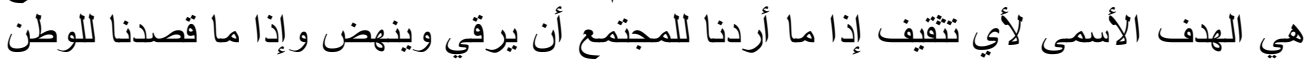

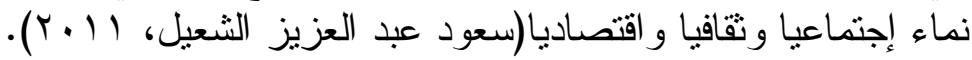

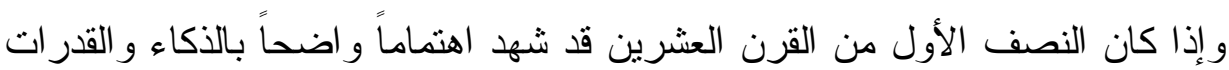

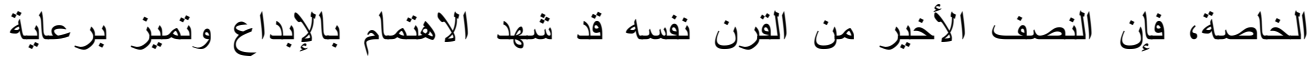

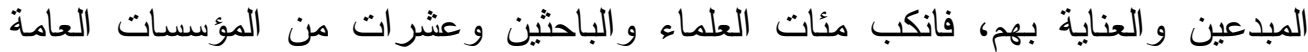

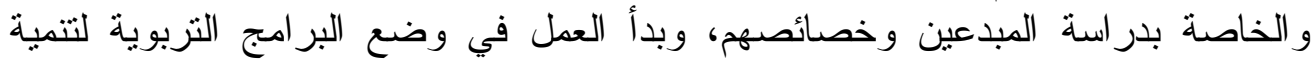

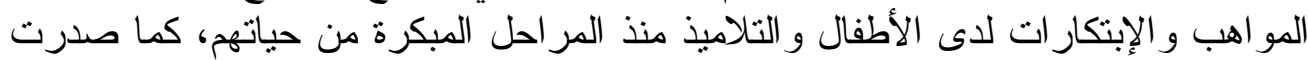

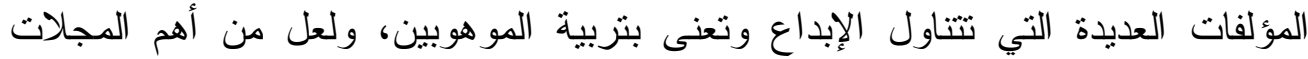


The Jornal Of Creative المتخصصة التي اهتمت ببحوث الإبداع مجلة السلوك الإبداعي Behavior

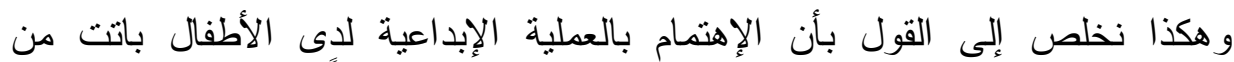

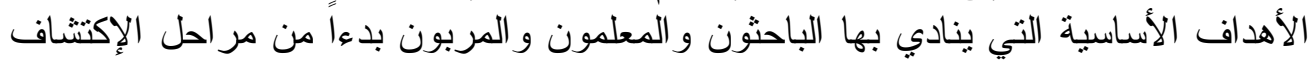

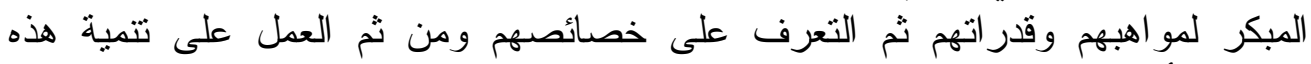

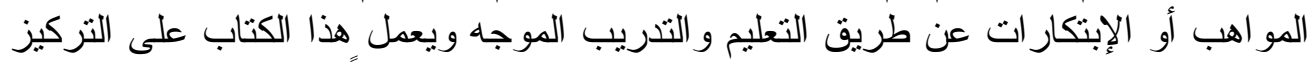

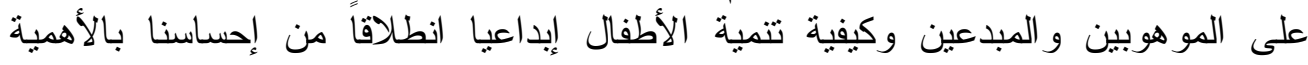

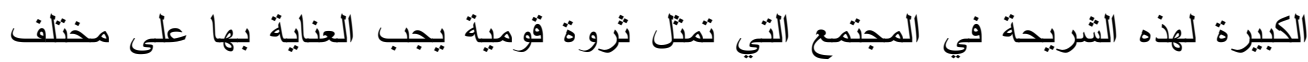

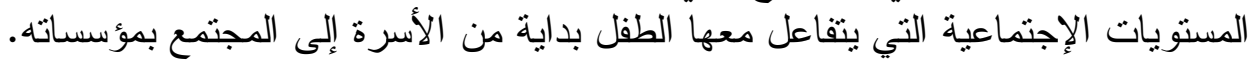

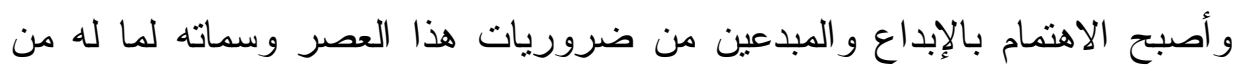

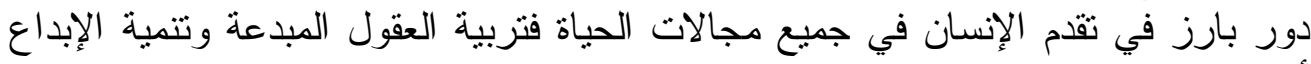

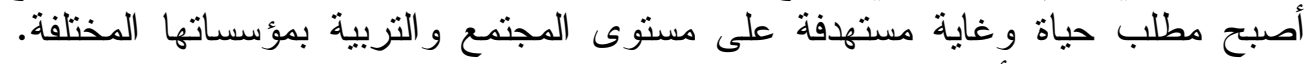

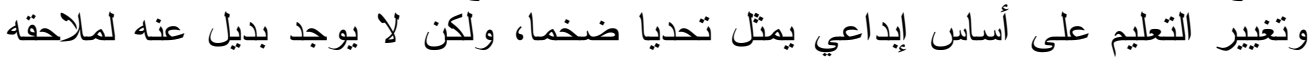

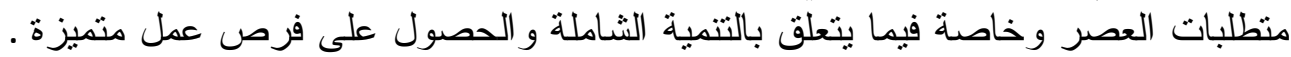

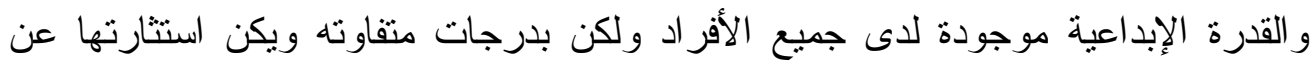

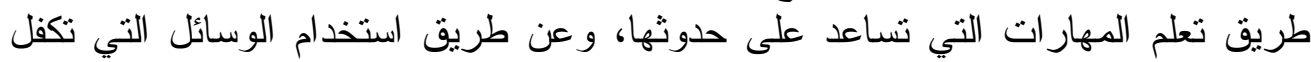

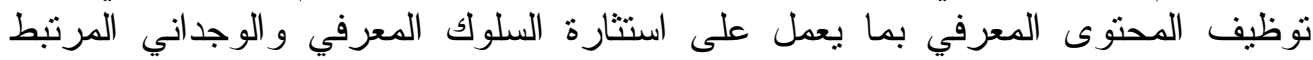

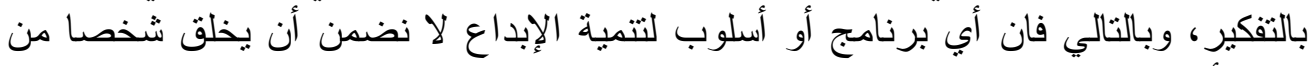

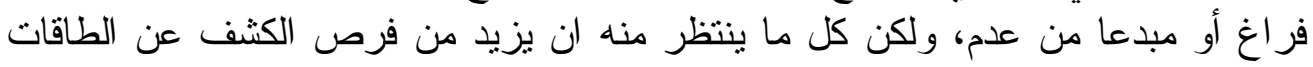
المبدعة لايه

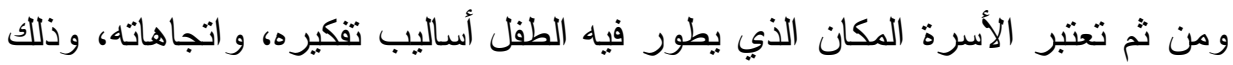

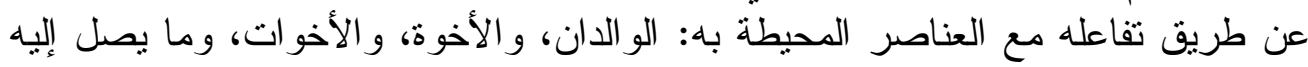

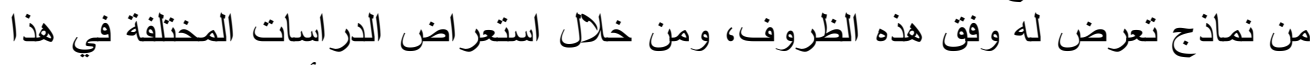

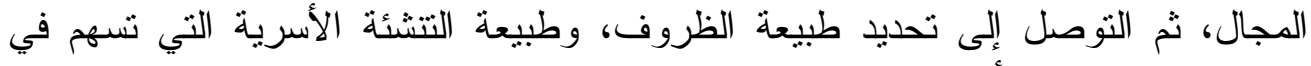
تطوير الإبداع لدى الأطفال.

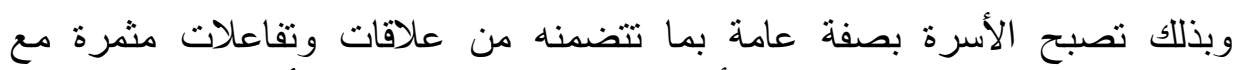

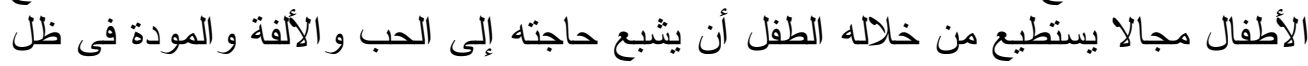

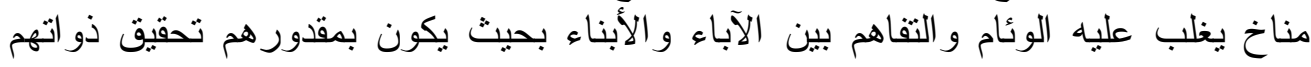

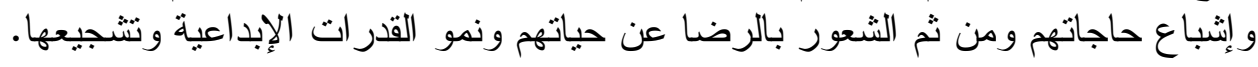

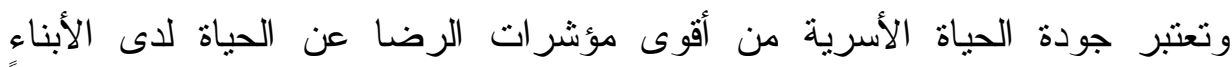

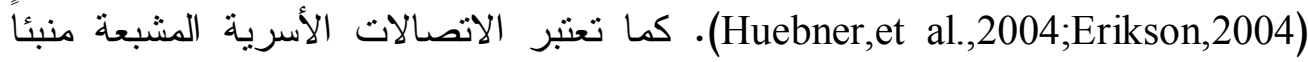

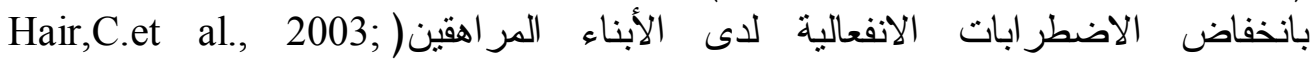
.(Benjamin,S.et al., 2004; Henery, C., 2006 
ونظر الأن الأسرة تعمل بوصفها نسق متكامل ومتو ازن للتفاعلات بين أعضائها وأن

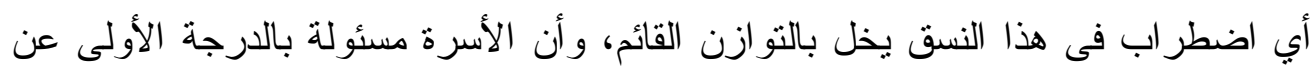

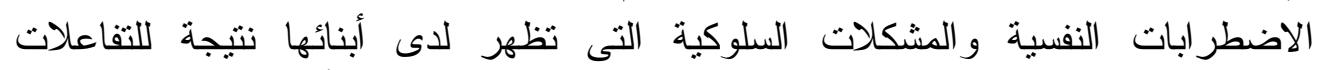

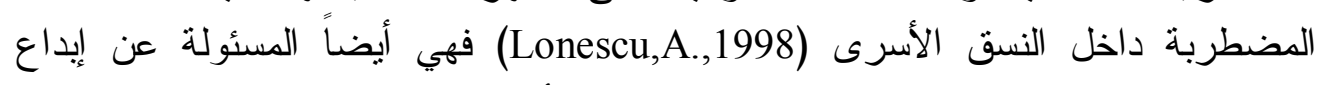
الطفل و إظهار قدر اته الكامنة وتتجيعها للوصول الإنى أعلى مسنوى لها.

إن الاهتمام بالجيل الجديد في جزء كبير منه ينصب على تتمية روح الإبداع لديهم،

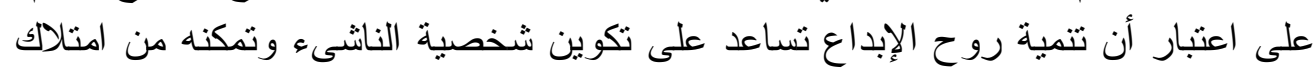

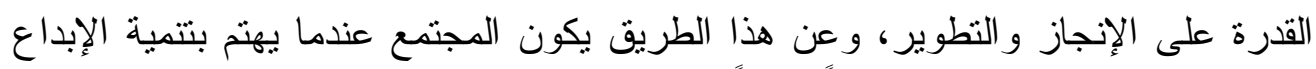

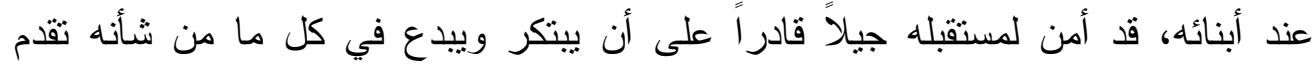

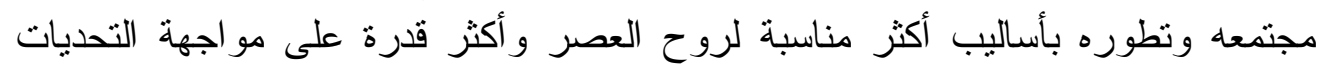

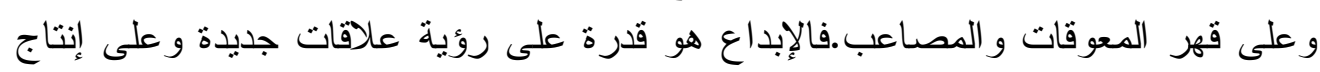
أفكار غير معتادة و البعد عن الثكل التقليدي في التفكير • إذ أن العملية الإبداعية هي تعل تعبيرً

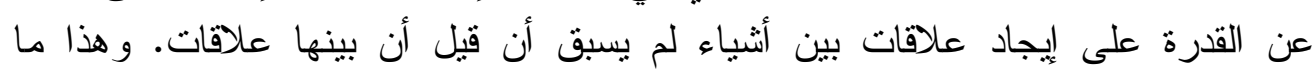

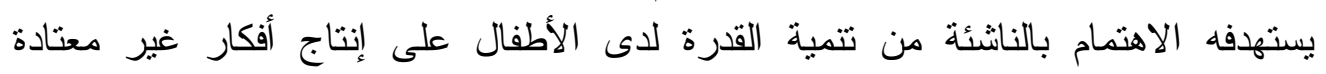

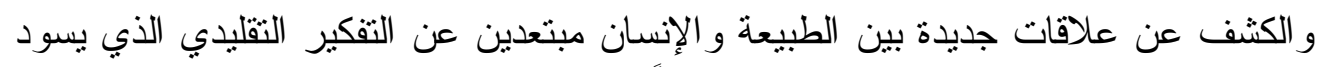

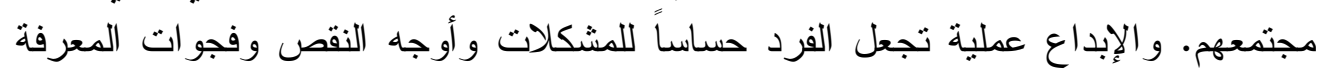

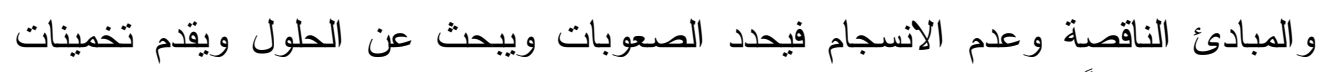

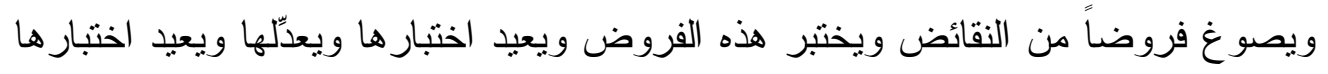
مرة أخرى ثم يقدم نتائجه في النهاية.

و هذا ما تهدف إليه التربية عموما لكي ينمو الطفل ويتدرج فى النمو حتى يصبح شاباً

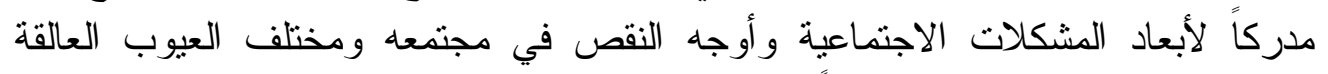

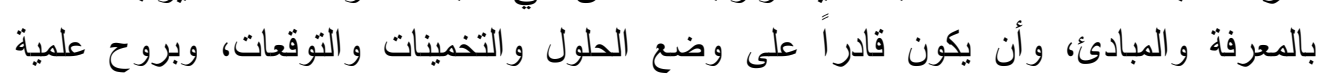
موضوعية يضع الفروض ويختبر ها حتى يثبت نجاحها في الوصول إلى النتائج المر غوبة.

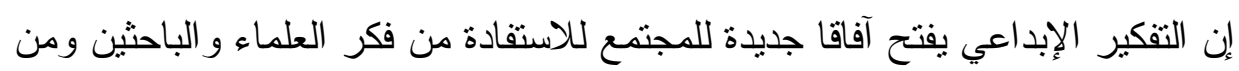

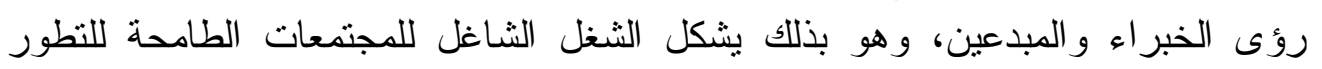

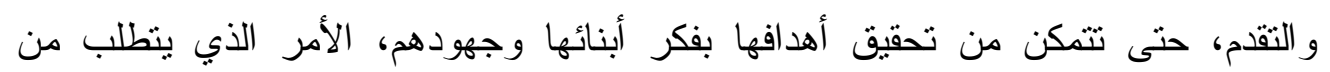

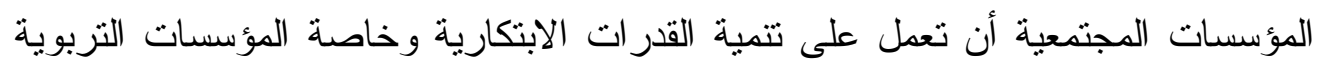

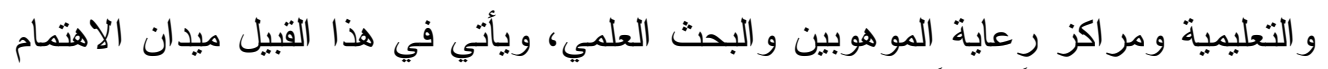

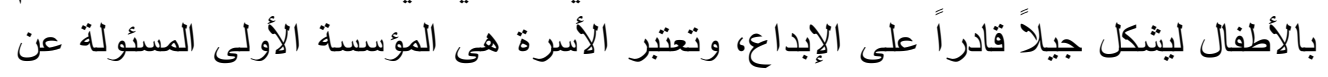
تتمية التفكير الإبداعي لدى الأطفال. 
يعتبر الإبداع وسيلة فاعلة يمتطبها المبدعون ليسهو ا في بلورة أفكار هم نظرياً، وفي إنجازها و اقعياً، ومن هنا تتبثق أهية التفكير الإبداعي من كونه قناة أكيدة إلى الإكتشافات

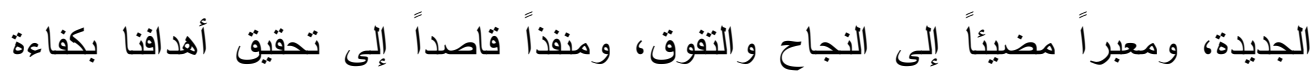

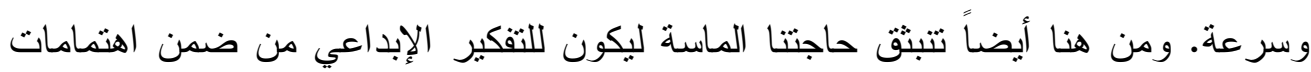
الأسرة المصرية، لتساهم في تطوير المو اهب، ورفع مستوى الأداء، وتحسين نوعية الحياة. ولذلك تتلخص مشكلة البحث في أهمية تطوير وتتمية الأسرة للقدر ات الإبداعية لأطفالها. وترى الباحثة أنه على الرغم من تعدد الدراسات و البحوث فى الأدبيات السيكولوجية

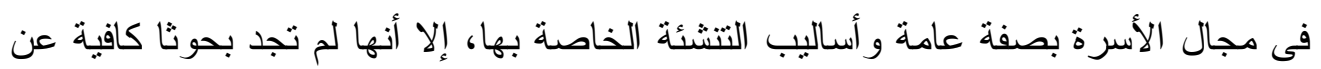

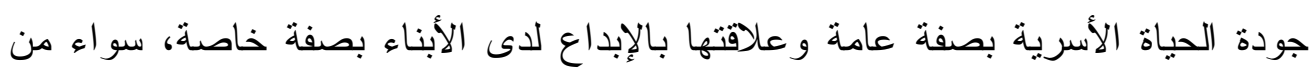

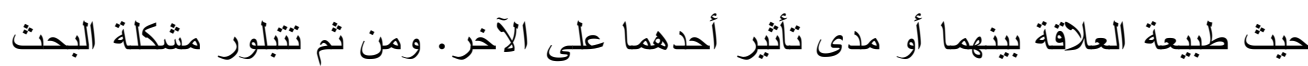
الحالي فى دراسة جودة الحياة الأسرية فى علاقتها بتتمية القدر ات الإبداعية لدى الأبناء.

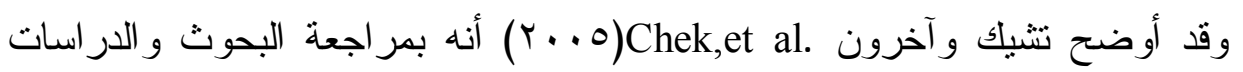
التى تتاولت جودة الحياة وجد قصور فى الدراسات الخاصة بجودة الحياة الأسرية سواء

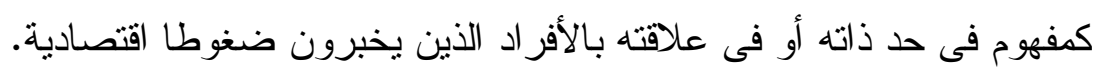

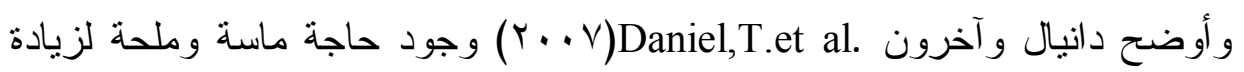

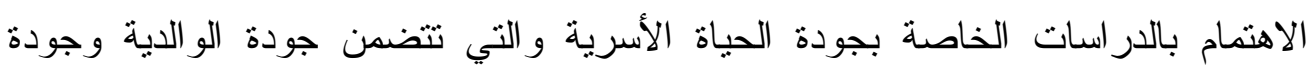
العلاقة بين الو الد-الطفل خاصة لاى المر اهقين فى المدارس الثانوية.

وبناء على ما سبق نجد أن هناك حاجة ماسة لوجود حياة أسرية جيدة لما يترتب عليها من نوافق نفسي واجتماعي ومستوى مرتفع من الصحة النفسية ومن ثم تتمية القدرات الإبداعية لاى الأبناء. هدف البحث: يهدف البحث الحالي إلى دراسة جودة الحياة الأسرية كما يدركها الأبناء وعلاقتها بتتمية القدر ات الإبداعية لديهم. 


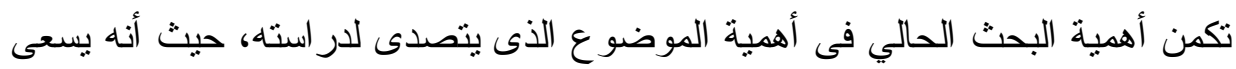

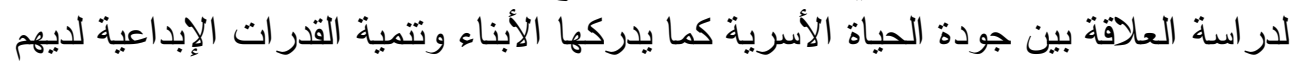
فمن الناحية النظرية: فعلى الرغم من الاهتمام بدر اسة العلاقات بين الو الدين - الطفل

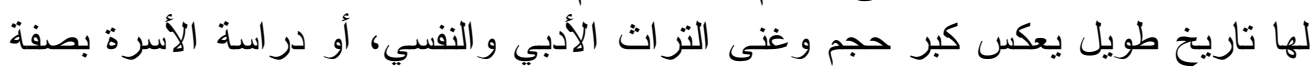

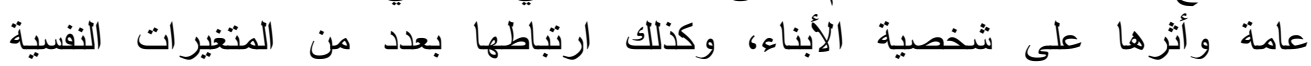

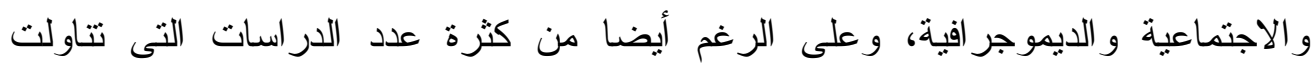

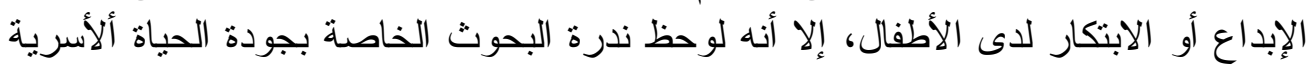

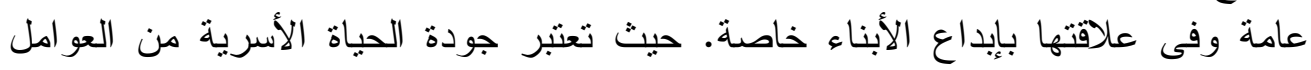

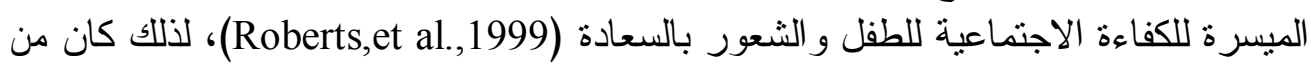
الأهمية فهم طبيعة العلاقة بين جودة الحياة الأسرية وتتمية القدر ات الإليداعية العية لاعى الطفل.

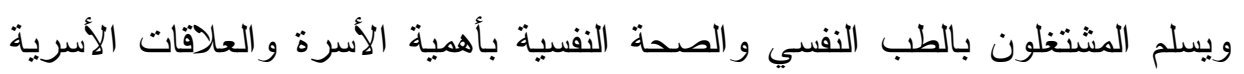

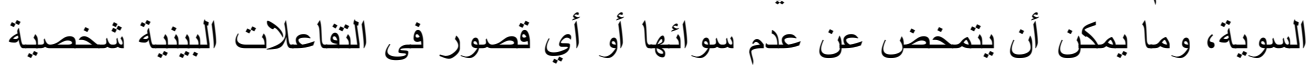

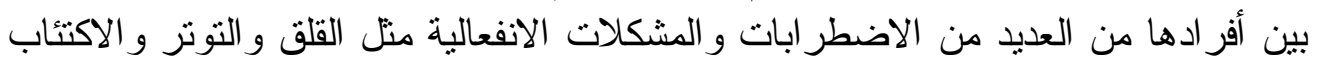

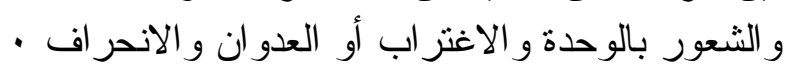

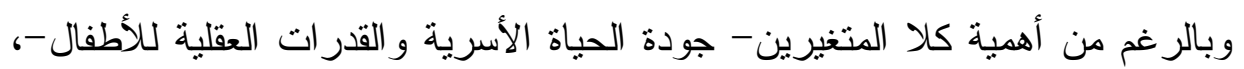

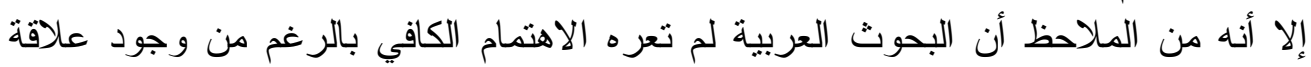
نظرية بين هذين المتغيرين.

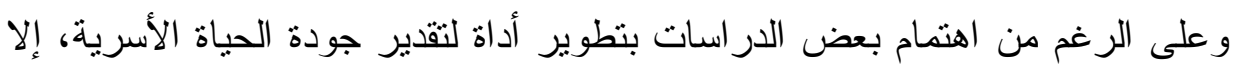

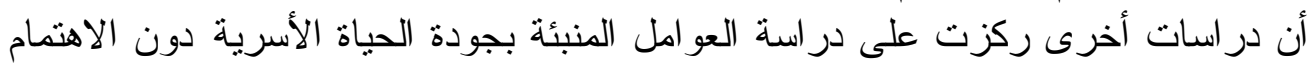

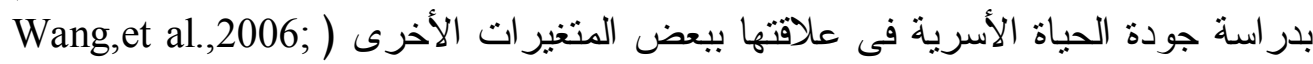
(Turnbull, et al., 2007 أما عن أهمية البحث من الناحية التطبيقية فهي تتمنل في توفير قدر من البيانات

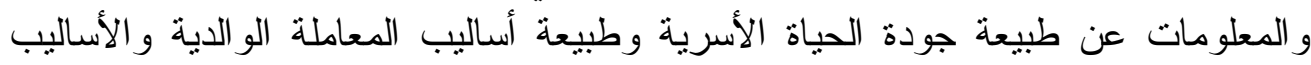

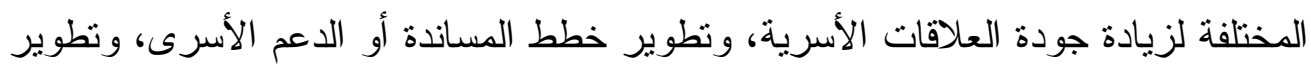

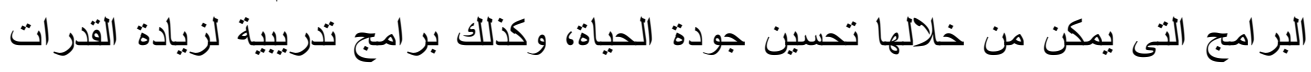
الإبداعية لديهم.

كما أن دراسة جودة الحياة الأسرية، قد يوفر قدراً من المعرفة يساعد الآباء على نهج

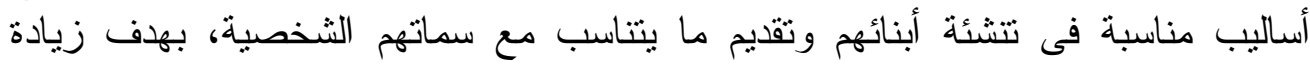

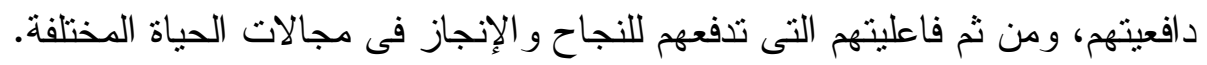




\section{الإطار النظري و المفاهيم الأسساسية:}

\section{أولاً: جودة الحياة الأسرية: Family quality of life (FQOL)}

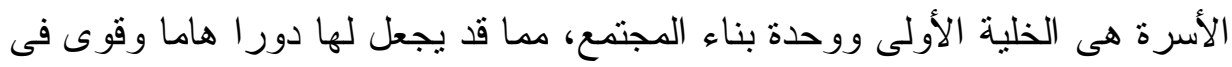
بناء شخصية الأطفال. ومن خلال الدعم النفسي والاجتماعي الألى الذئى تقدمه الأسرة للطفل

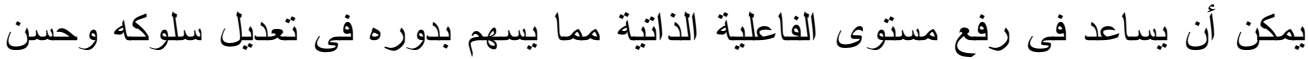

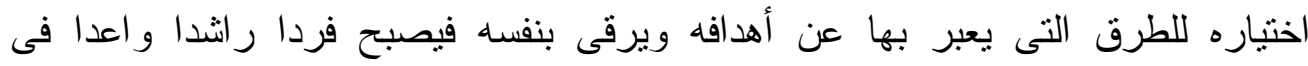
المجتمع(Turnbull,A.,et al., 2004).

وقد أثنار عدد من الباحثين إلى أن الأهمية الكبرى للأسرة بوصفها الخلية الأولية التى لثى من خلالها تتحدد فى رحابها شخصية الفرد المستقبلية، وأن الثكل الذى تتم به تتشئة الطفل

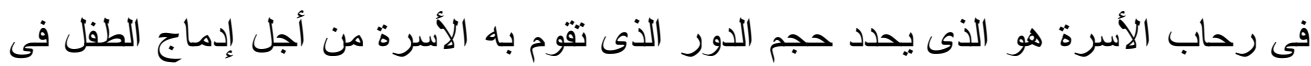

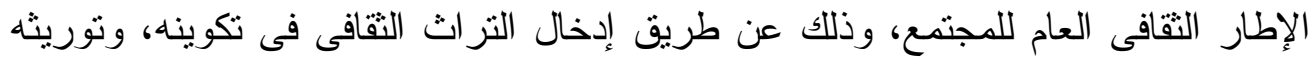
إياه بتعليمه نماذج السلوك المختلفة فى المجتمع الذى ينتسب إليه، وتدرييه على طريقة

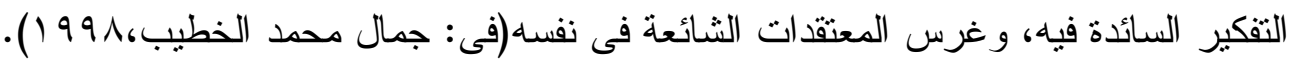
ويعتبر مفهوم جودة الحياة quality of life (QOL) من المفاهيم التى نادراً ما حظيت

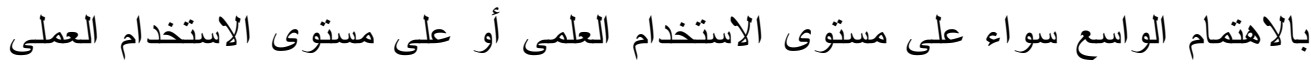
العام فى حياتتا اليومية، غير أن مستخدمى هذا المفهوم لم يتفقو ا بعد على معنى محدد لهذا الها

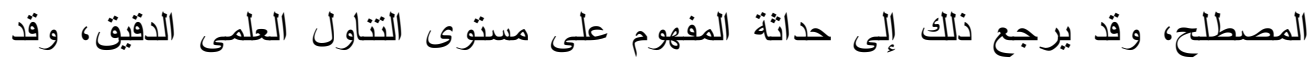
تطرق هذا المفهوم للاستخدام فى العديد من العلوم، حيث يستخدم أحيانا للتعبير عن الرقى لئى لئى لئى

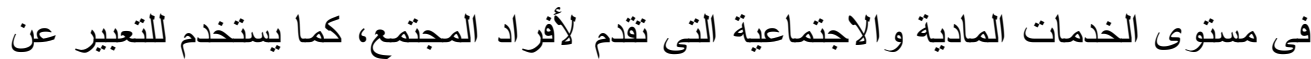

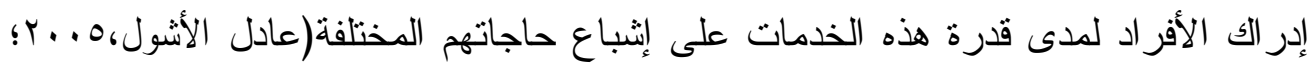

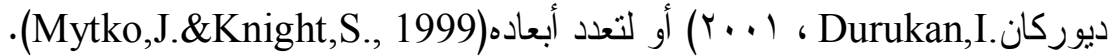

ويرى دنيس وآخرون . Dennis,et al( 1999 (أن جودة الحياة للفرد فى جوهرها

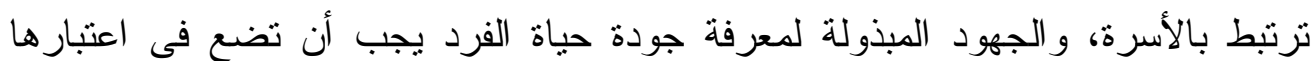

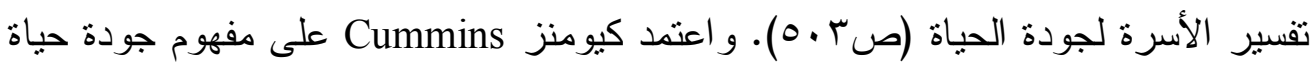

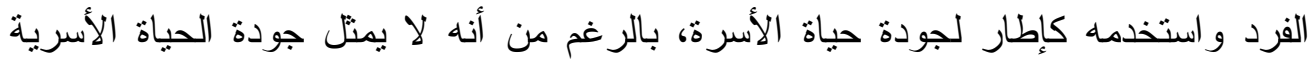

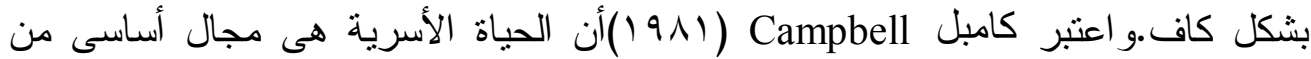

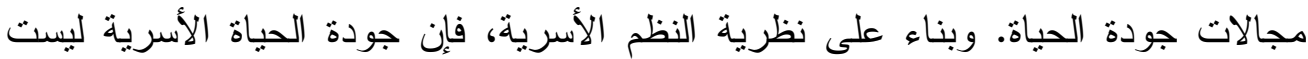

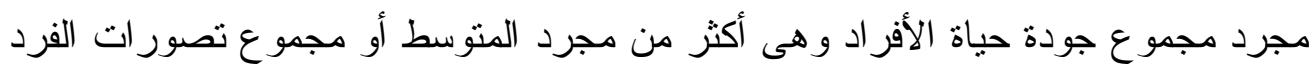

.(Broderick, 1993) 
ويعتبر جيمس . James, K (Y. . . الحياة الأسرية للأطفال و المر اهقين أحد مؤشرات جودة الحياة وبعد أساسى من أبعادها.

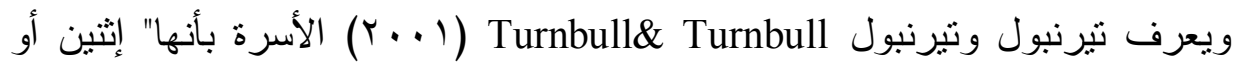

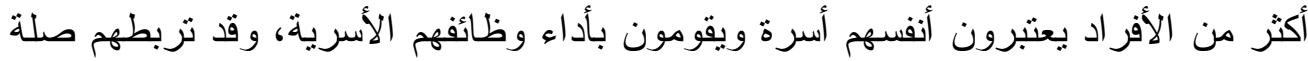
الدم أو الزواج أو لا، وليس بالضرورة النيرون أن يعيشو ا معا.

ويعرف باترسون وجرويك Patterson\&Garwick( 99 () الأسرة فى أوسع معانيها

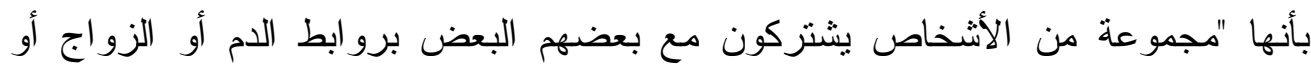

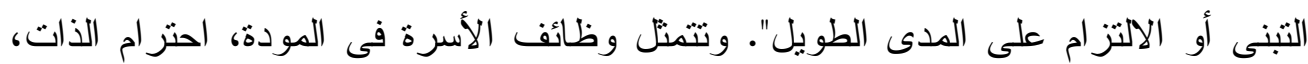

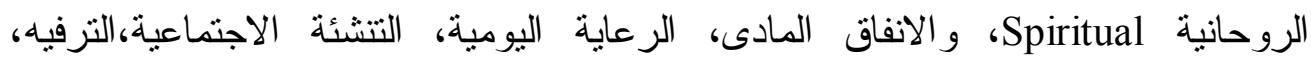
و التعليم(Gallimore, etal.,1998).

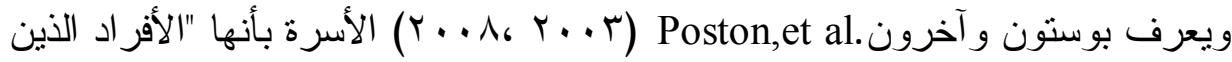

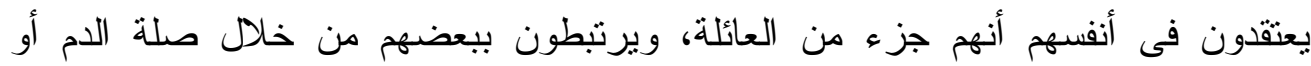

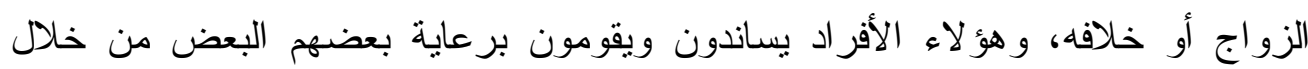

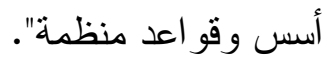

ويعرف مركز الثاطئ المعنى بالإعاقة Beach Center on Disability الأسرة بأنها"

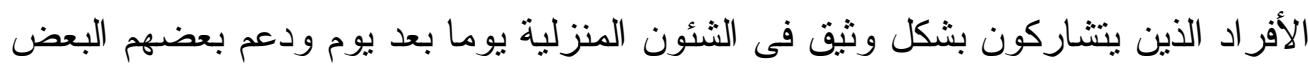

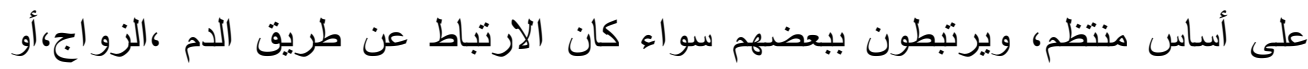
علاقة شخصية وثنقة(Rillotta,et al.,2011).

وأوضحت برونز افت.Bronzaft,A (1997) فى دراسة لها أن المعاملة الجيدة،

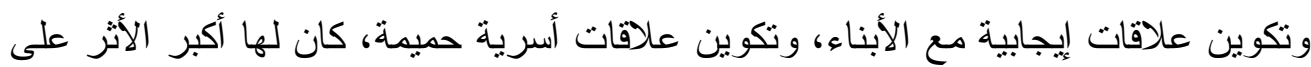

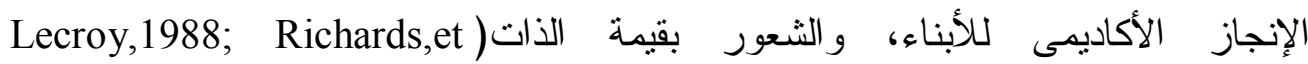
.(al.,1991;Wenk,D., et al.,1994 وتعتبر جودة الحياة الأسرية من الموضو عات التى زاد الاهتمام بها فى الآونة الأخيرة

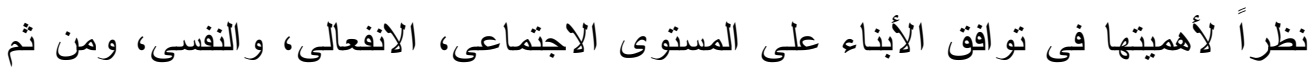
رفع مستوى الصحة النفسية لديهم ( Aznar\&Casta,N.,2005; Turnbull,B.\& Turnbull .).,2006

ويعزى مفهوم جودة الحياة الأسرية إلى السعادة الثاملة للأسرة و القدرة على إثباع احتياجاتها و الاستمتاع بالحياة. وقد تم اثتقاق هذاة المفهوم FQOL من مفهوم جودة الحياة 
ويرى كل من براون وبر اون Brown\&Brown (T . . إ) أن جودة الحياة الأسرية هى" الدرجة يحتاج فيها أفر اد الأسرة إلى الالتقاء، و الددى الذى يستمتعون فيه بوقتهم معاً، و المدى الذى يكونون فيه قادرون على فعل أثنياء هامة مع بعضهم البعضي".

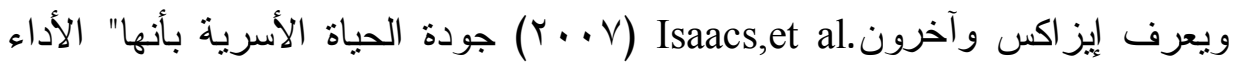

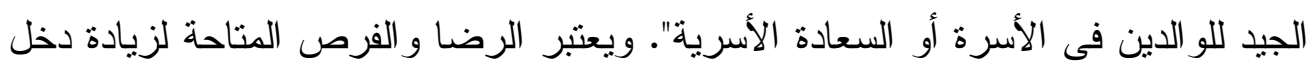
الأسرة أو فرص الاشتراك فى أنشطة وقت الفراغ تعتبر من أهم مؤشرات جودة الحياة الأسرية.

وتعتبر جودة الحياة الأسرية ظاهرة تتمو وتتسع فى مجال بحوث الأسرة، وقد اهتمت البحوث فى جودة الحياة الأسرية على أساس معرفة مدى جودة حياة الفرد و والممارسات

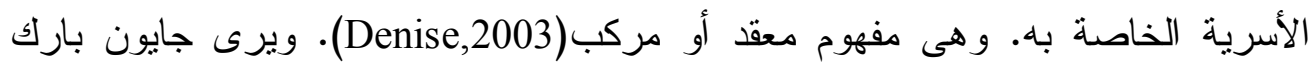
تعإ Jiyeon,Park Turnbull,et ) تعريف جودة الحياة الأسرية يعتبر تعريف معقد، ويواجه تحديات كبير الهيرة .(al.,2000

وتتحدد جودة الحياة الأسرية بعدد من المظاهر الداخلية و الخارجية، وترتبط المظاهر الداخلية بكيفية رؤية الأسر لأنفسهم من الناحية الوظيفية من حيث: الصحة، العلاقدات

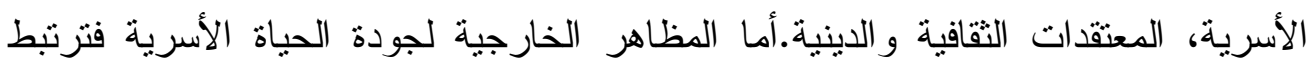

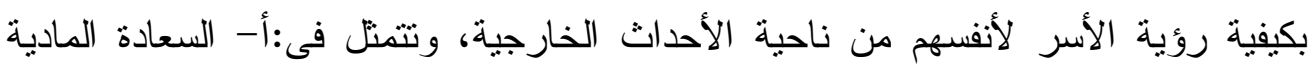

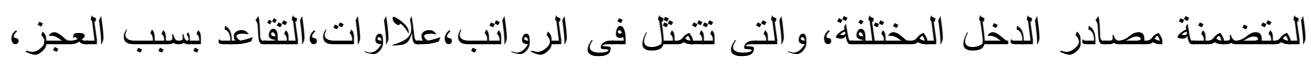

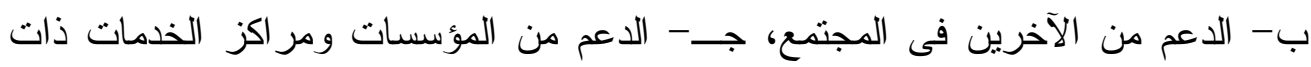

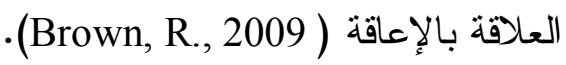
*** وترى الباحثة أنه قد يخلط البعض بين جودة الحياة الأسرية وأساليب المعاملة الو الدية

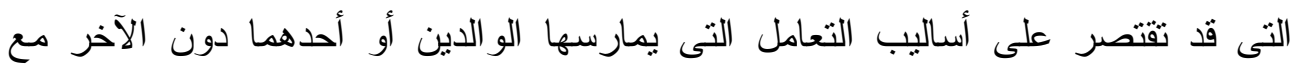

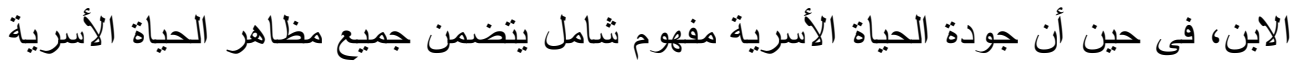
بما تتضمنه من أبعاد(الو الدية، التفاعل الأسرى، السعادة الانفعالية، الحالة المادية المنيسرة

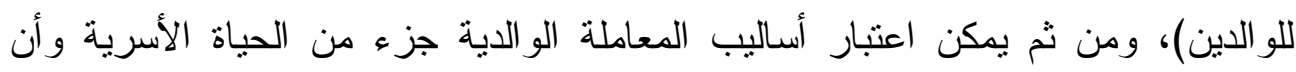
الحياة الأسرية مفهوم أكثر شمولية من أساليب المعاملة الو الدية. 


\section{مبادئ جودة الحياة الأسرية:}

تتحقق جودة الحياة الأسرية عندما: ا-تشبع احتياجات الأسرة.r-بستمتع أفر اد الأسرة

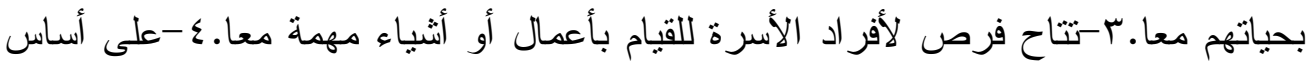

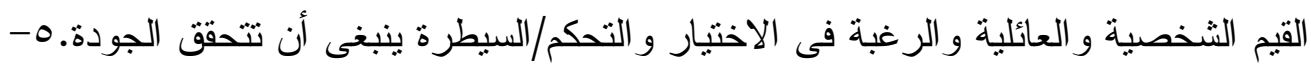

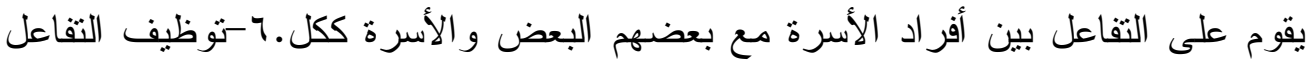
فى المجالات المختلفة من خلال الأسرة(Denise,J.,2003). ثانياً: مفهوم التفكير الإبداعي: Creative Thinking.

تعددت التعاريف التي تتاولت مفهوم الإبداع، ويعزى ذللك الاخــتلاف إلـى اخــتلاف

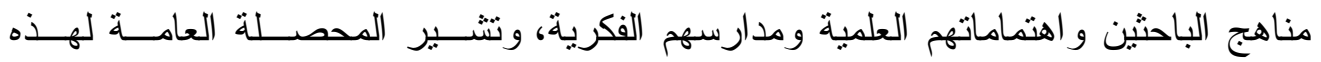

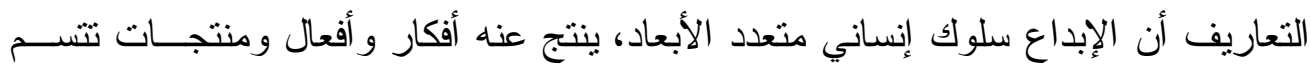

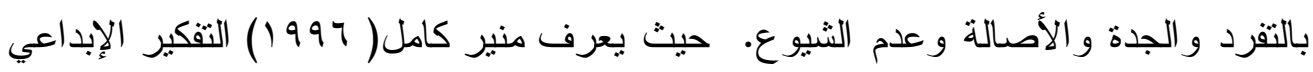
بأنه "الأسلوب الذي يستخدمه الفرد في إنتاج أكبر عدد ممكن من الأفكار حول المشكلة الني

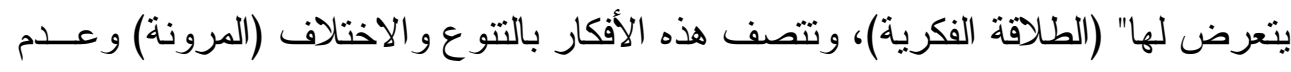
النكر ار أو الثيوع (الأصالة).

ويعرّق الإبداع بأنه "مزيج من الخيال العلمي المرن، لتطوير فكرة قديمة، أو لإيجــاد

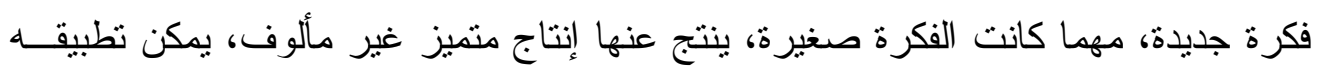

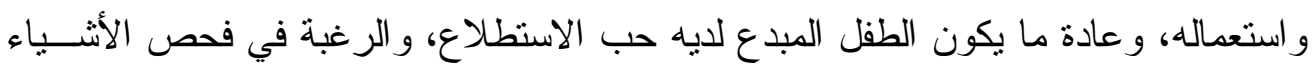

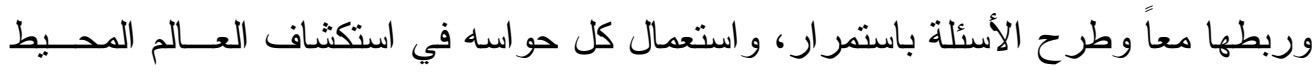

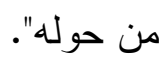

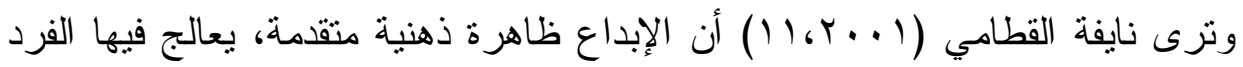
الأثياء و المو اقف والخبرات و المشكلات بطريقة فريدة أو غير مألوفة أو بوضع مجموعة

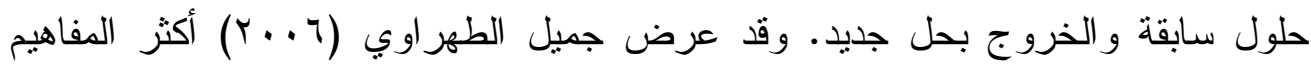

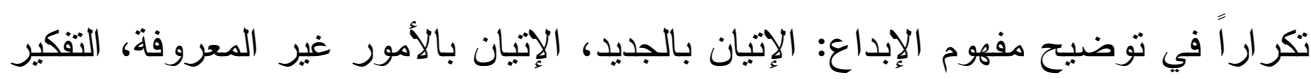

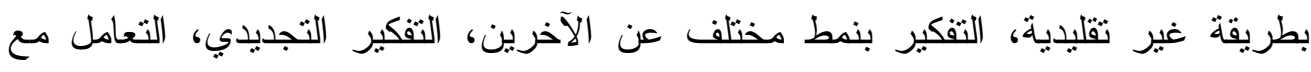
القضايا بطريقة غير معروفة، إعادة ترتيب مفردات الو اقع بشكل جمالي. 


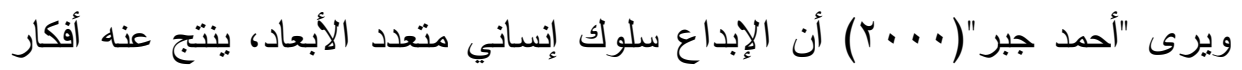

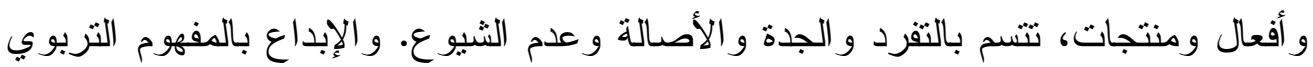

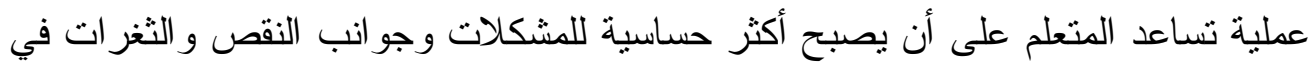

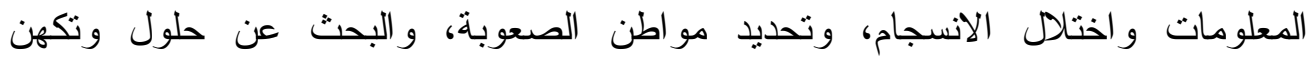

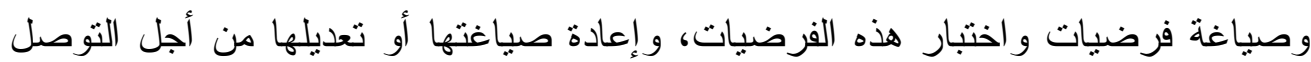
إلى نتائج جديدة ينقلها المتعلم للآخرين.

وترى الباحثة أن الإبداع هو " قدرة وطاقة واستعداد يكتسبه الطفل من خلال التركيز

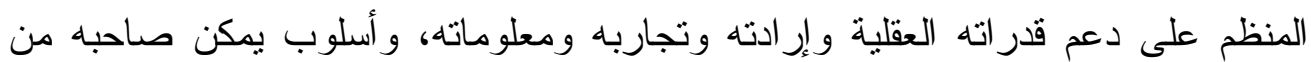

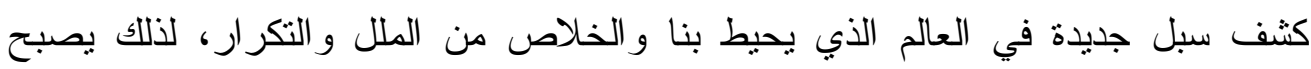
الإبداع المادة الأساسية للطفل في عمليات التغير و التطوير".

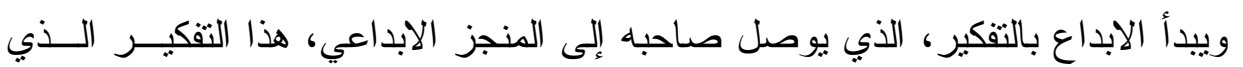

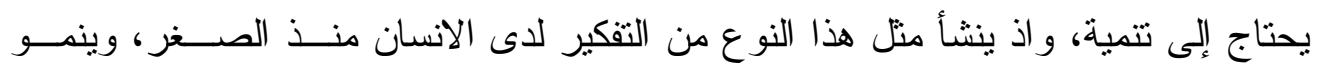

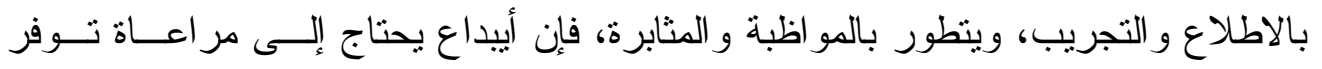

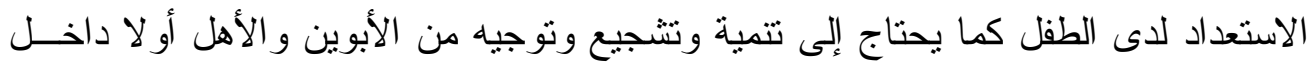

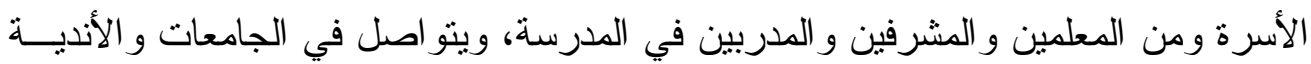
و الرو ابط و المر اكز الثقافية و الاجتماعية و الرياضينة.

وتعتبر السنوات المبكرة في حياة الطفل هي الأكثر حرجاً، فقيها تبدأ عمليــة تشــكيل

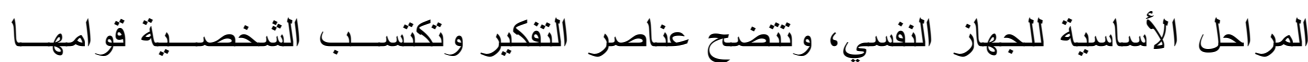

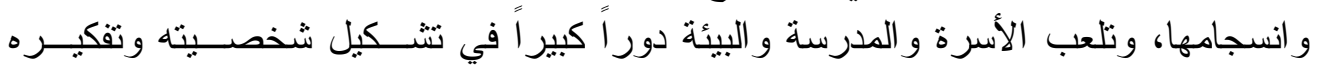
الابداعي عن طريق التعرف على ما يمتلك من قدر ات ونوظيفها مستقبلاً في أعمال و وأفكار ابداعية.

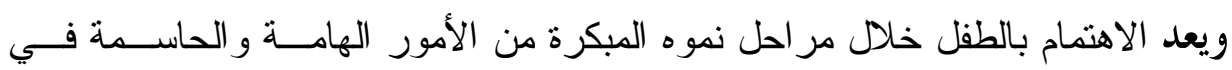

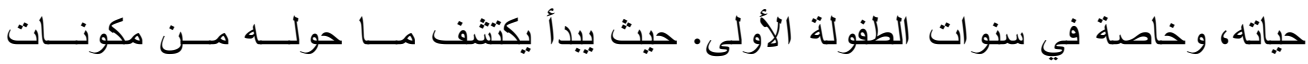

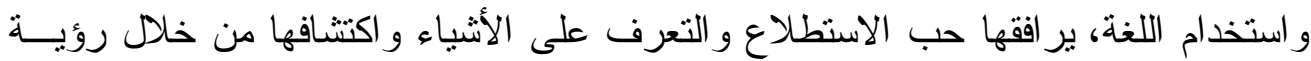

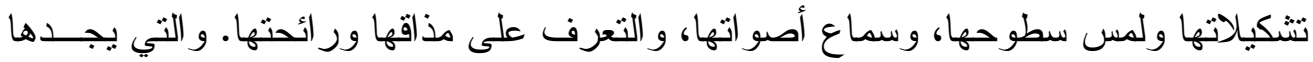
تختلف من مثير لآخر . تمكن

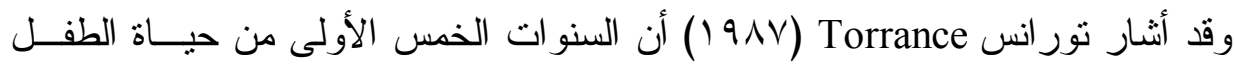

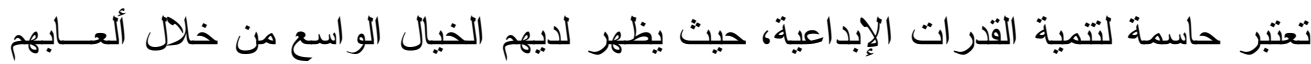

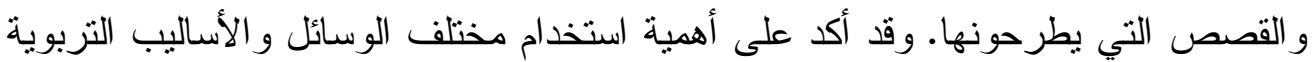

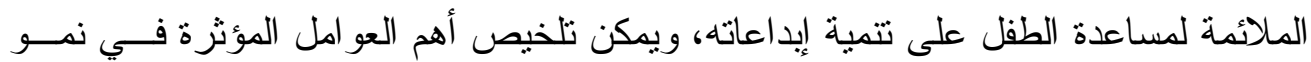

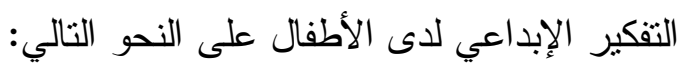




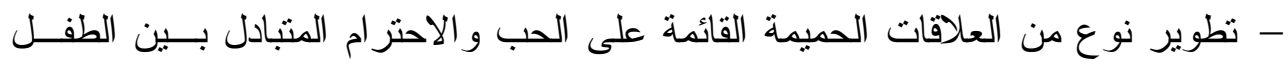
وو الديه و الأفر اد المحيطين به في العأسرة.

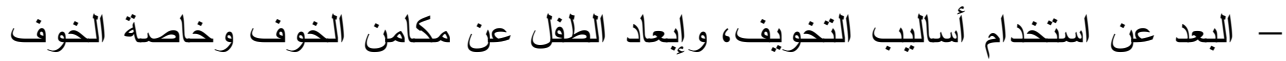

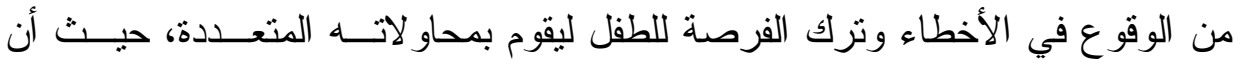

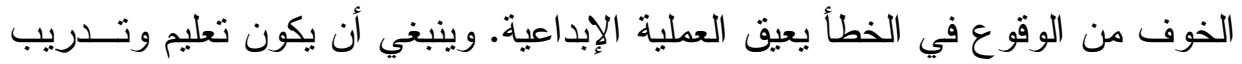

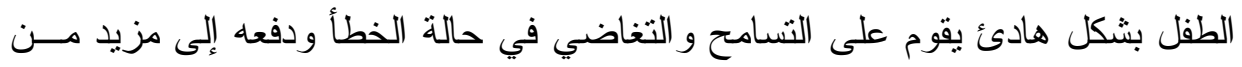
الاكتثاف و التجريب، و هذه تتكل أحد أساسيات التقكير الإبداعي (Torrance, 1987).

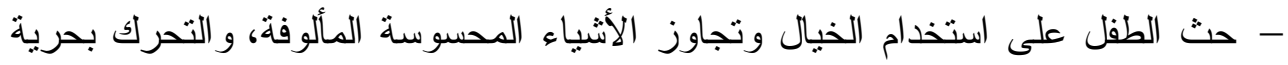

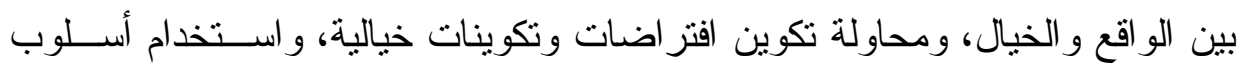

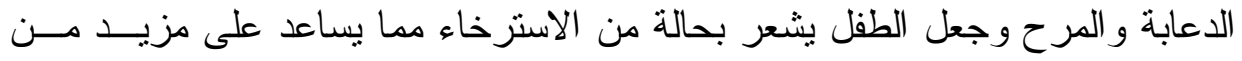

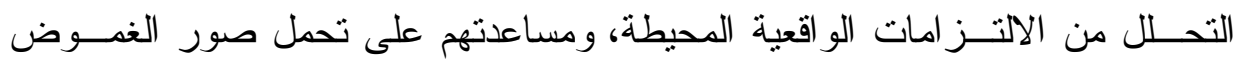

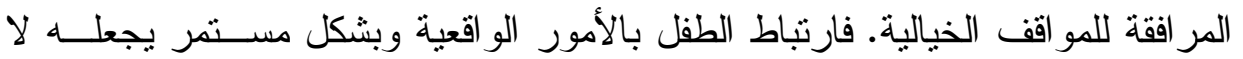
برغب أو يستحسن التفكير الخيالي ( Torrance,1987; Davis,1990). - تربية الطفل على المرونة في التفكير و عدم التصلب، وترك الحرية للاختيار واتخـاذا

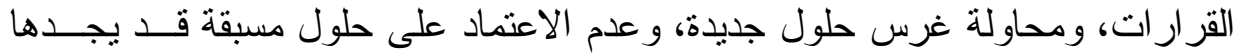

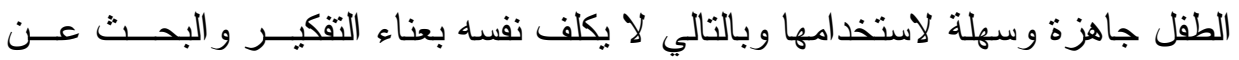

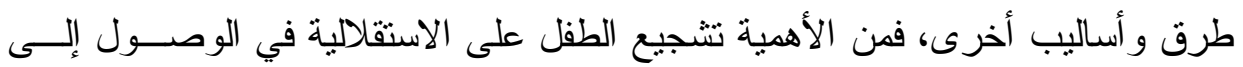

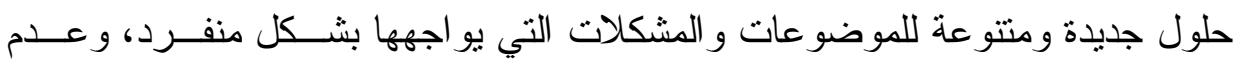

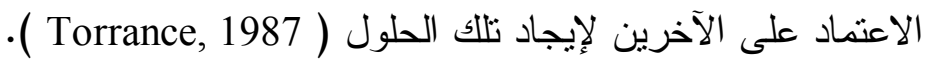

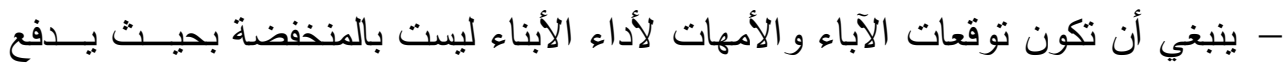

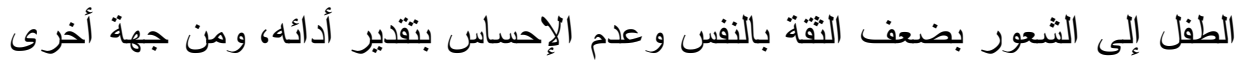

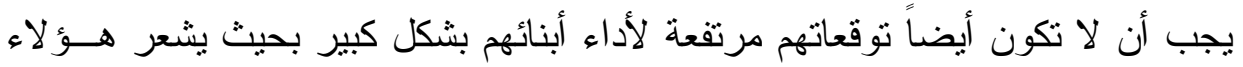

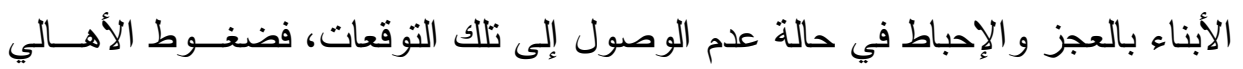

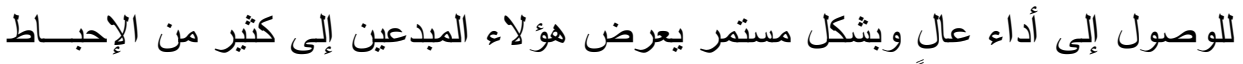

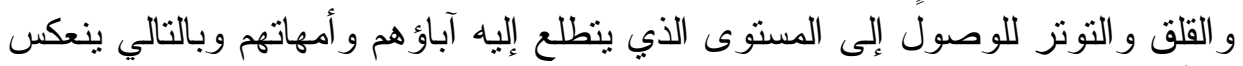

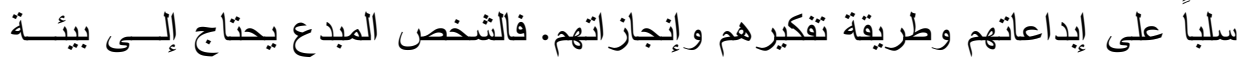

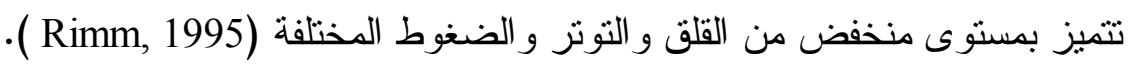

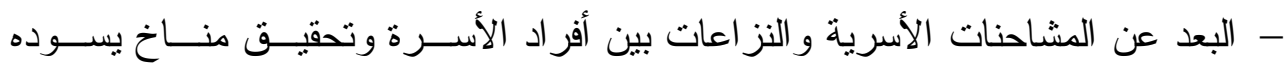

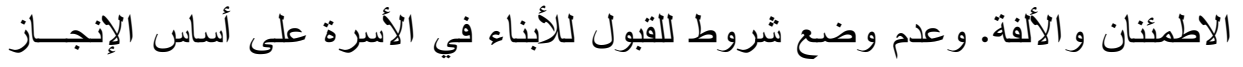

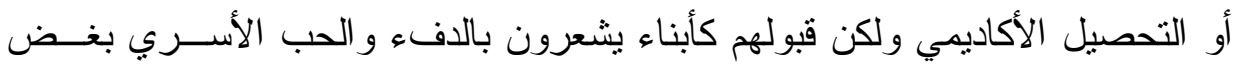

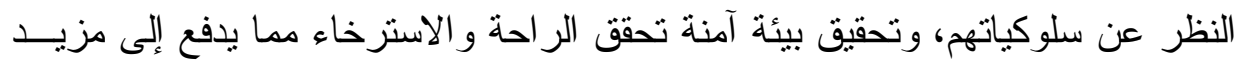
من الخيال للوصول إلى إيداعات ذات طابع فريد و أصيل (Silverman, 1991). 
هذا؛ وقد تعددت الأبحاث و الدر اسات التي نتاولت الأساليب التربوية المناسبة من قبل

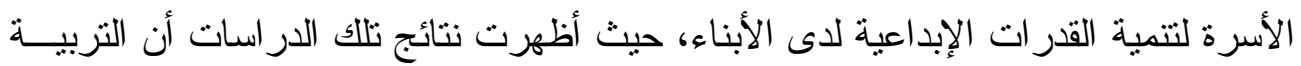

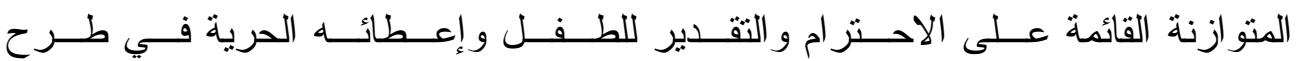

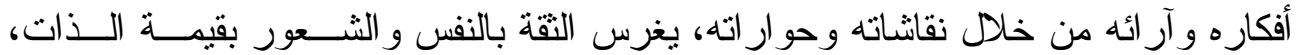

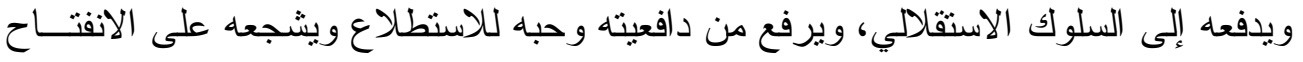
على تجارب أخرى جديدة ( Torrance, 1987; Milgram,1990; Csiksyentmihaly,1991;

(Cropley,1992

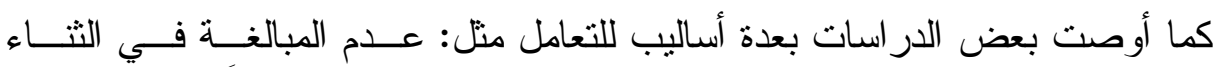

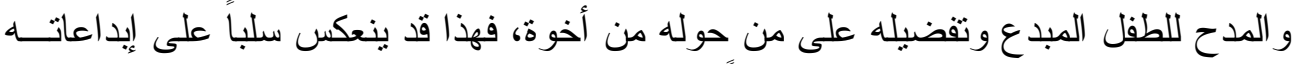

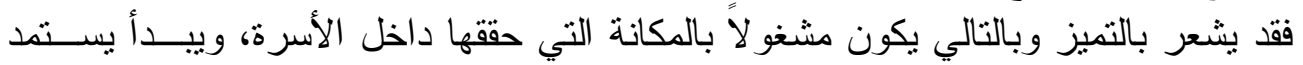

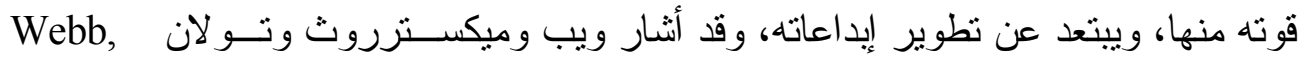
و Meckstroth \&Tolan

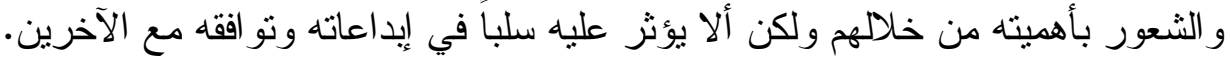

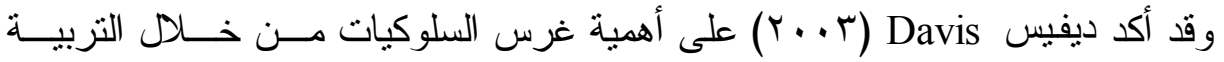

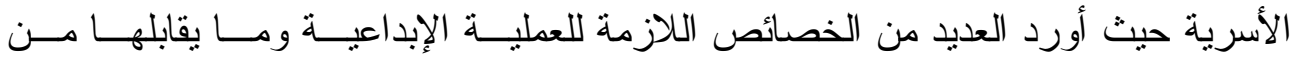

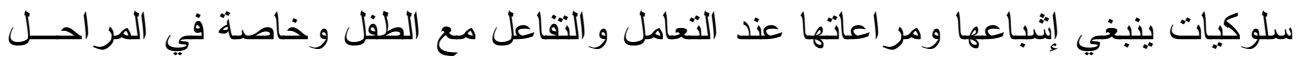

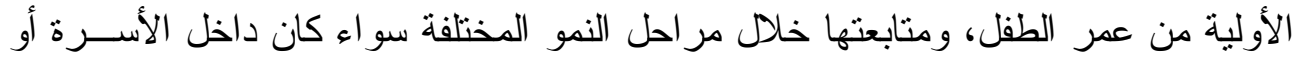
عند التحاق الطفل بالمدرسة.

\section{جودة الحياة الأسرية وتنمية القدرات الابداعية:}

مما لا شك فيه أن الأسرة هى المنوطة فى المقام الأول بتكوين الجوانــب المختلفـــة

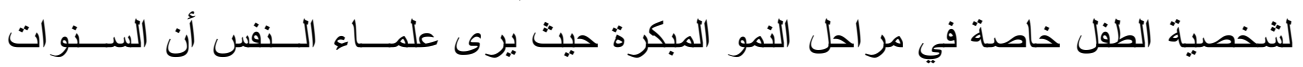

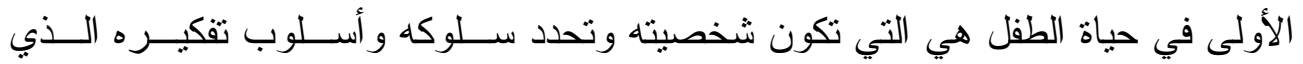

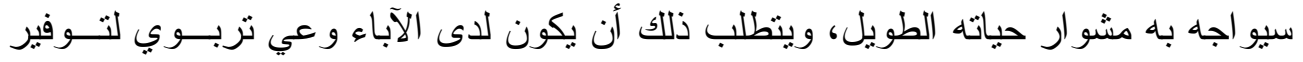

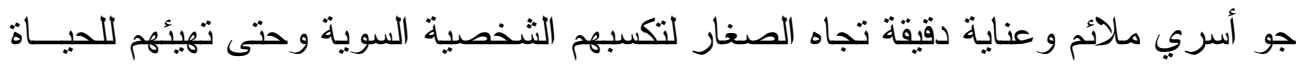

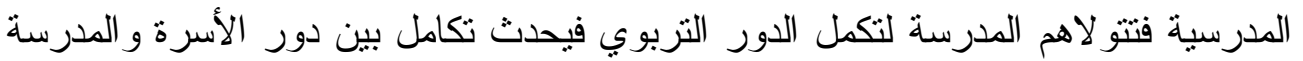

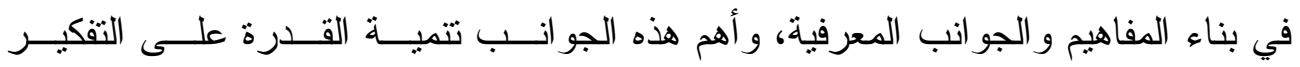

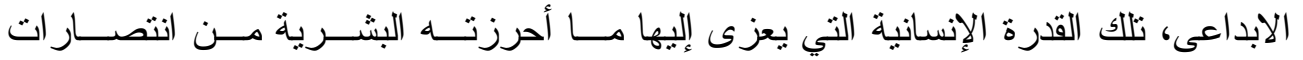

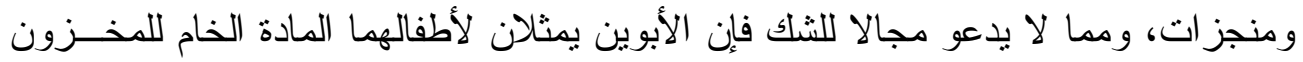

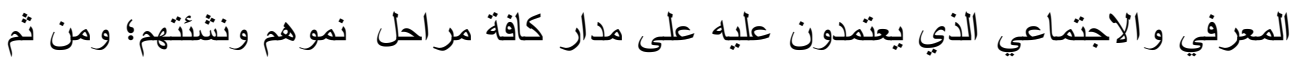

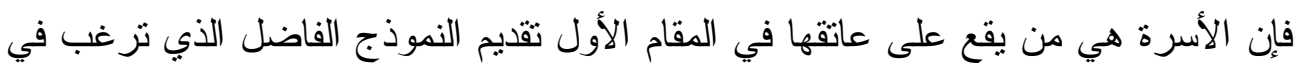
نقله إلى الأبناء و اسنتباط مو اهبهم وقدر اتهم المنتوعة. 
ويفيد العديد من علماء النفس أن السنوات الخمس الأولى من حياة الطفل هي الأكثـر

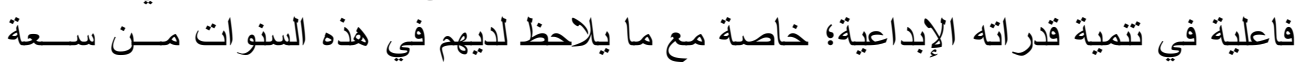

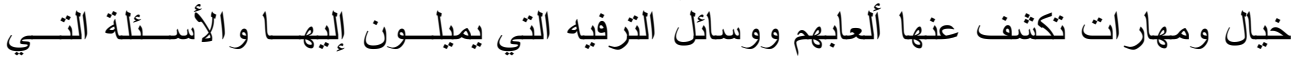

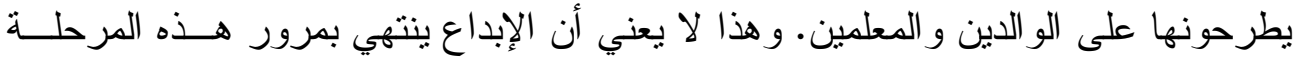

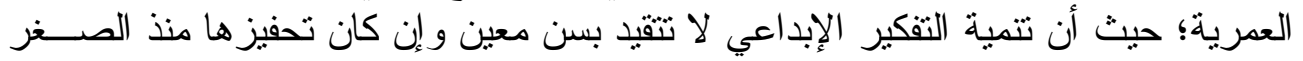

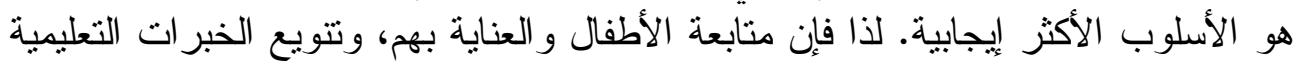

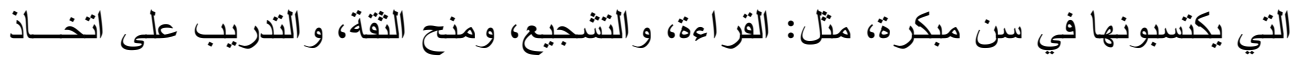

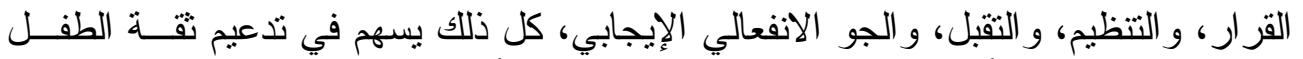

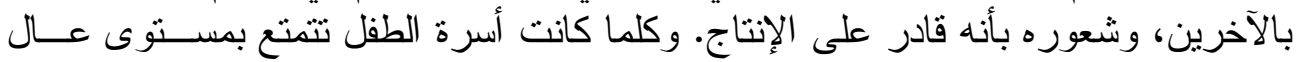

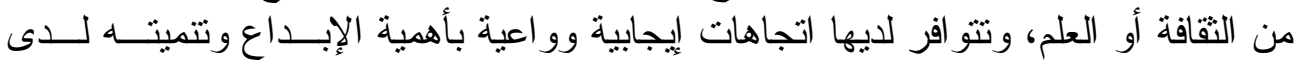

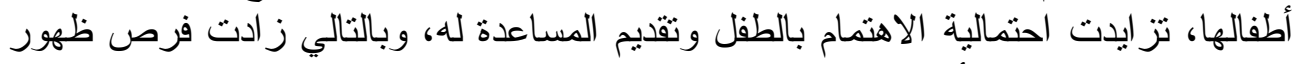
الإنتاج الإبداعي عند الأطفال.

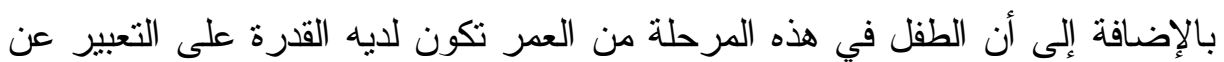

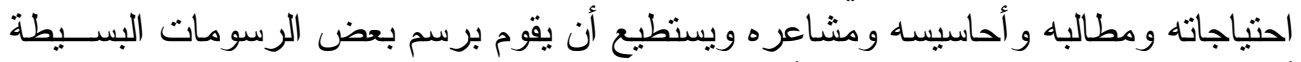

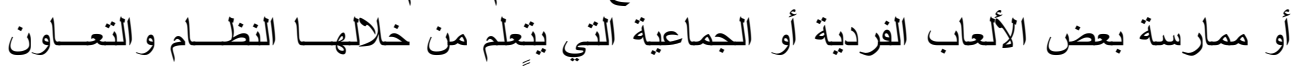

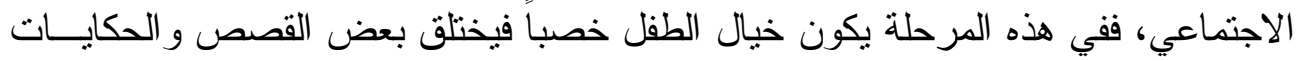

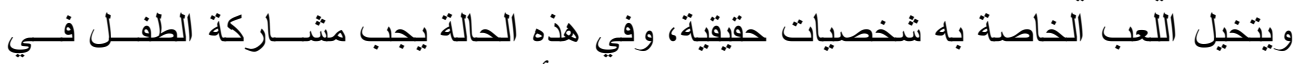

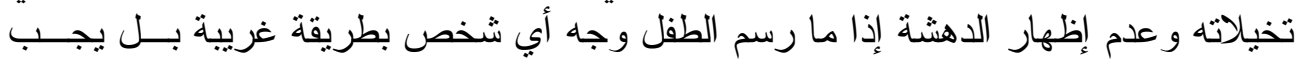
تشجيعه حتى يتعلم الرسم بطريقة سليمة.

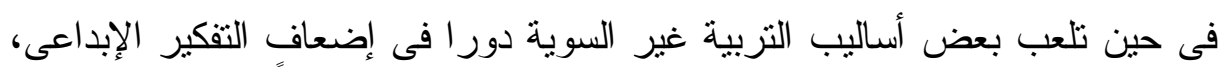

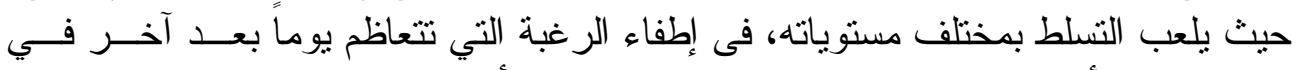

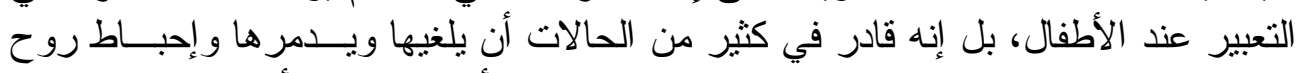

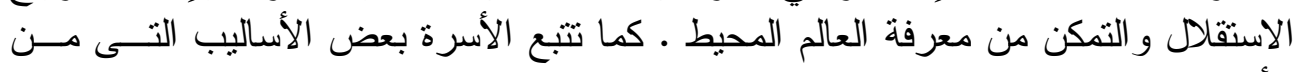

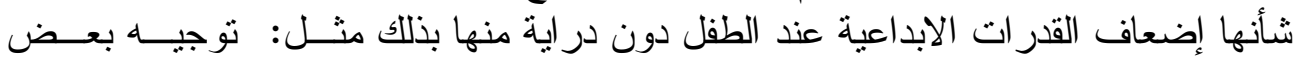

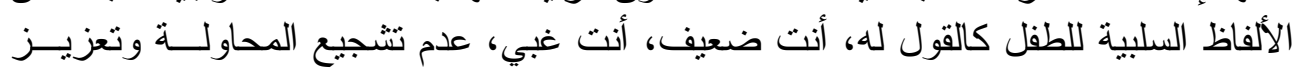

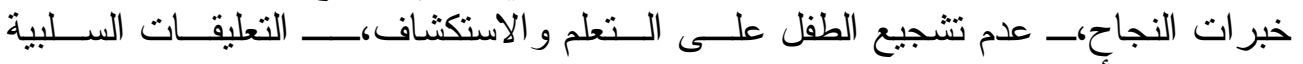

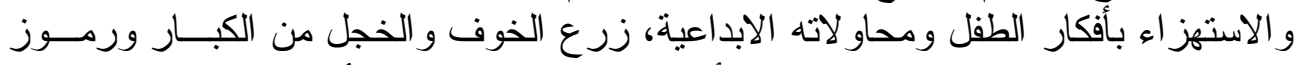

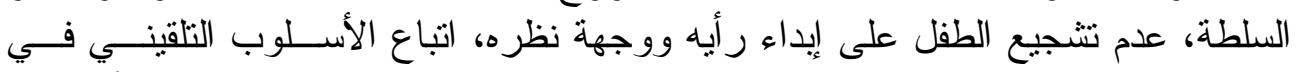

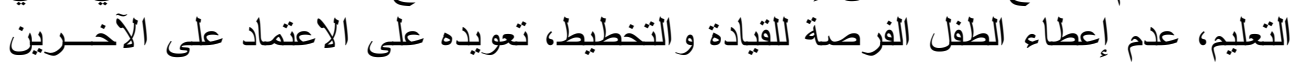

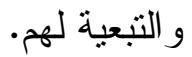

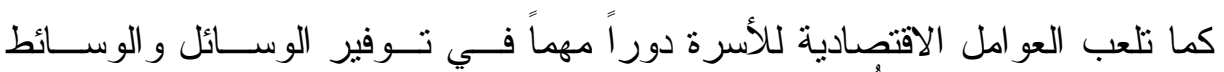

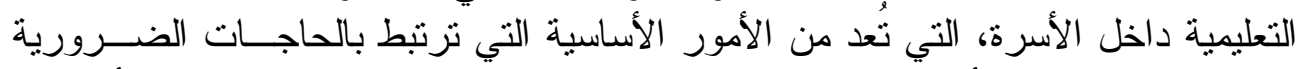

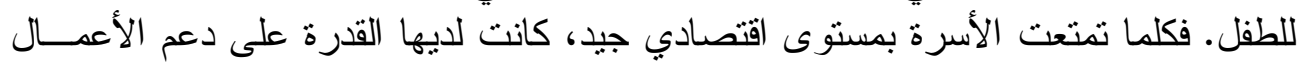

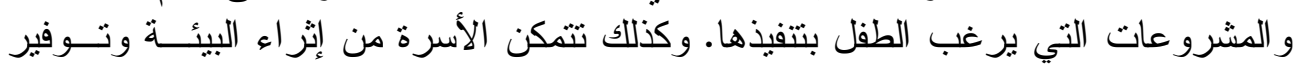
المصادر وتتويعهاً لغايات تتمية إبداعات أطفالهم. 


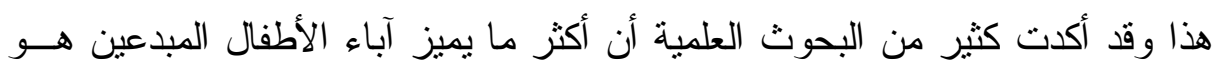

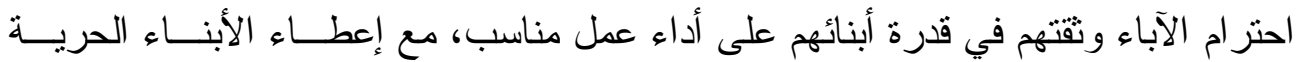

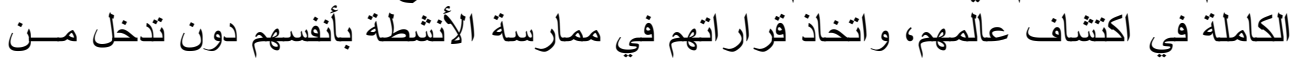

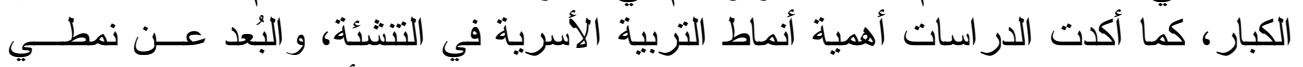

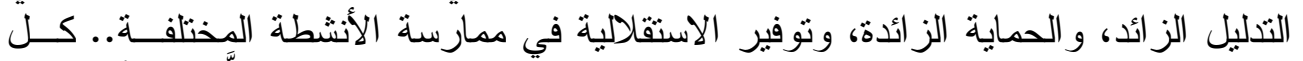

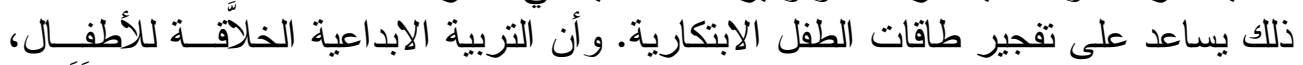

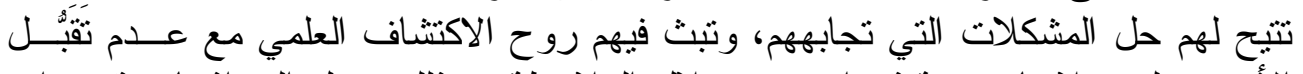

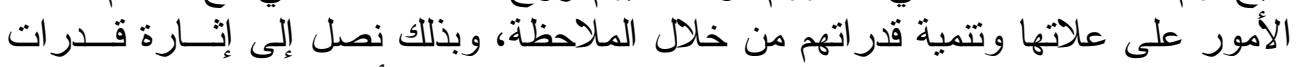

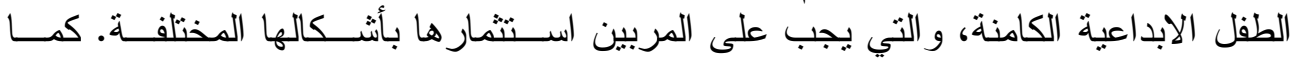

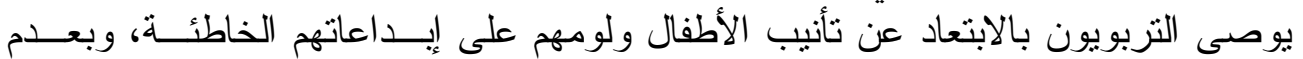

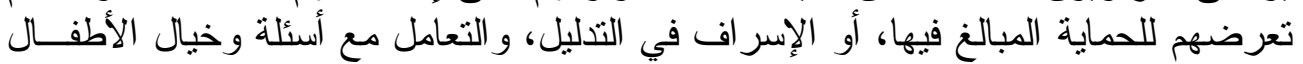

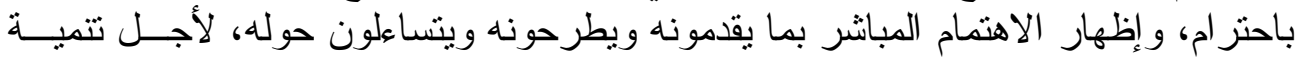

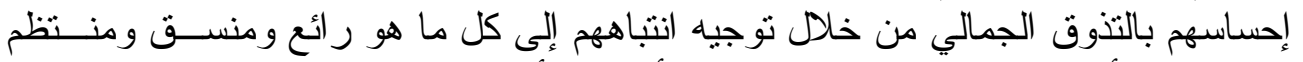

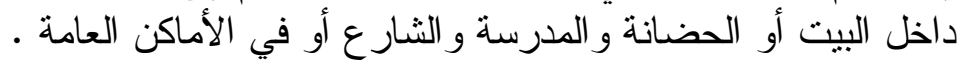

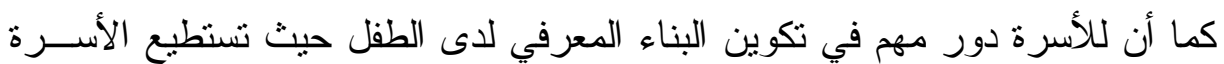

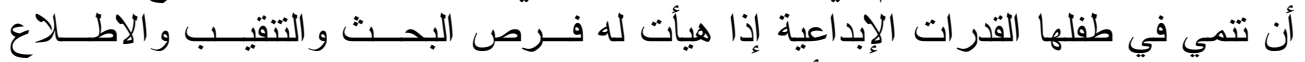

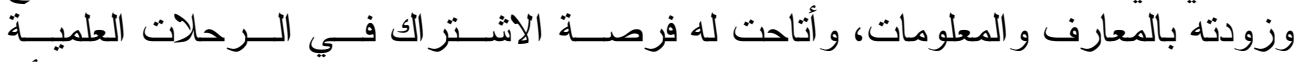

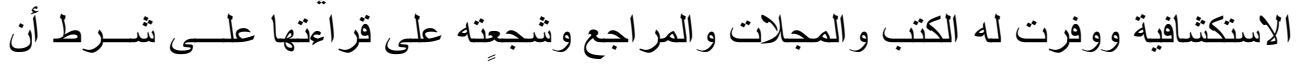

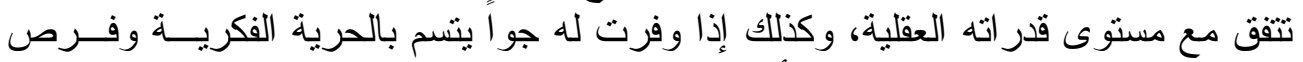

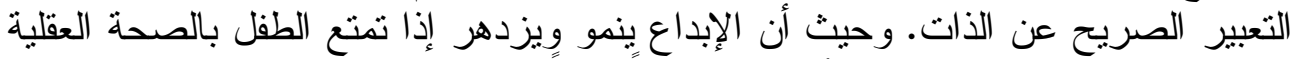

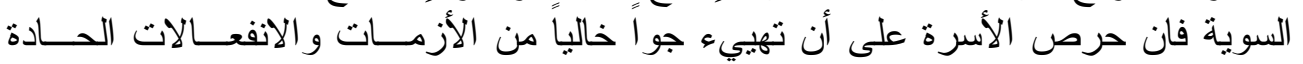

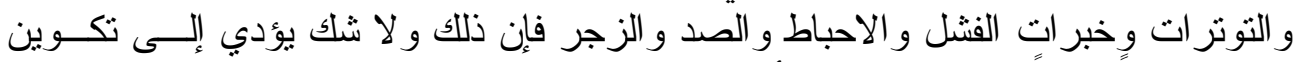

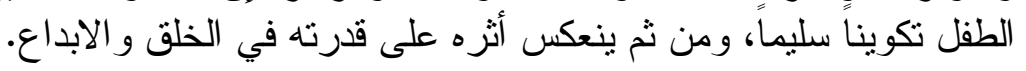

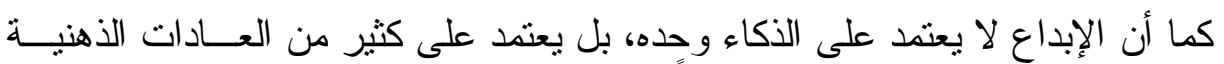

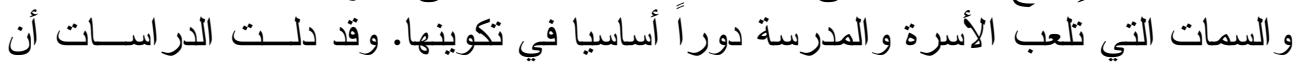

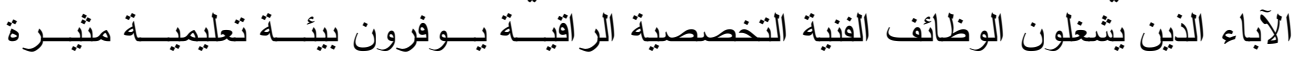

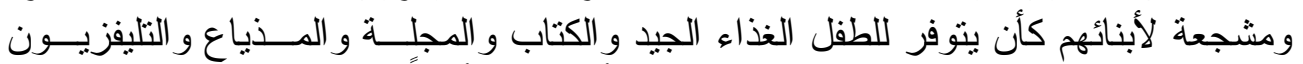

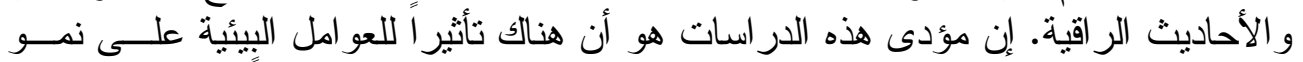

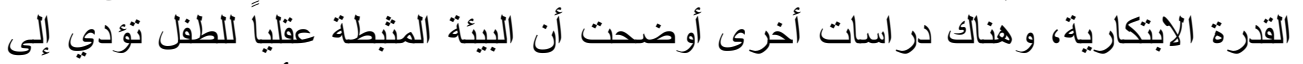

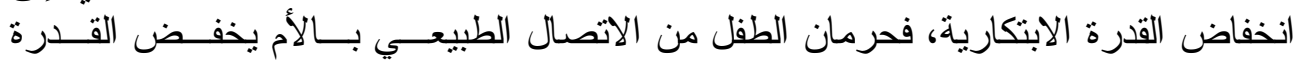

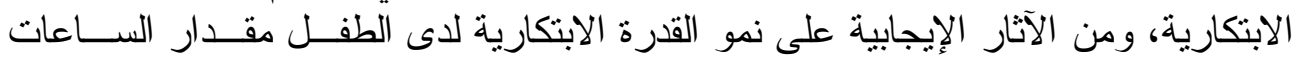

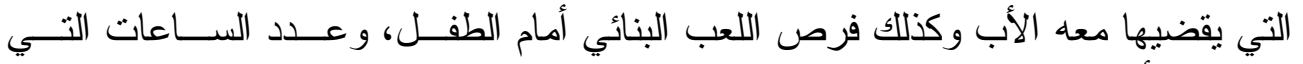

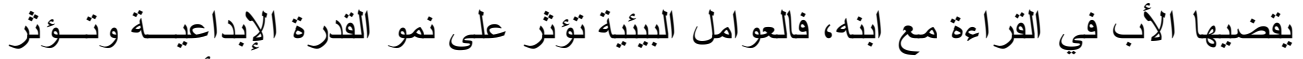

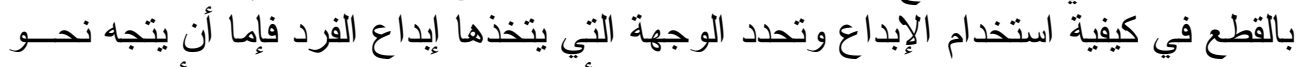

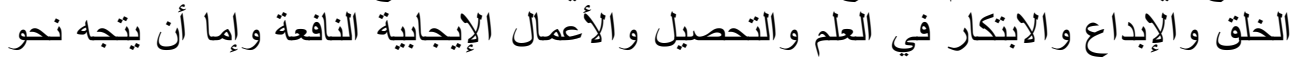
الإبداع في مجال السرقة و الآجريمة و الانحر واف. 


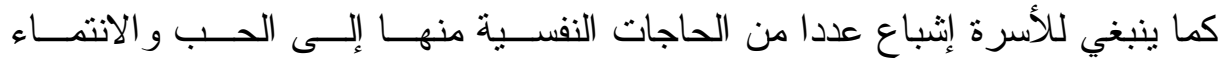

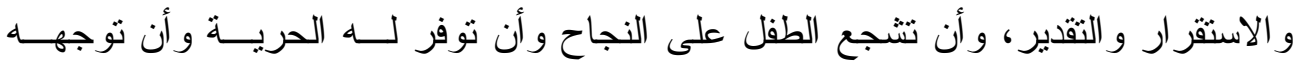

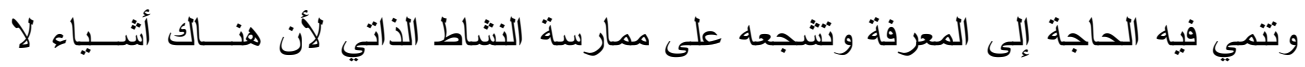
يمكن تعليمها إلا عن طريق بذل النشاط الذاتي منل السباحة.

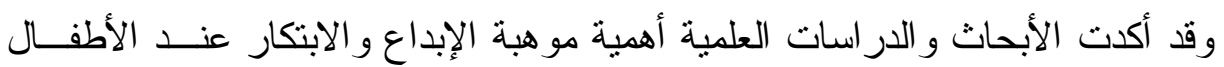

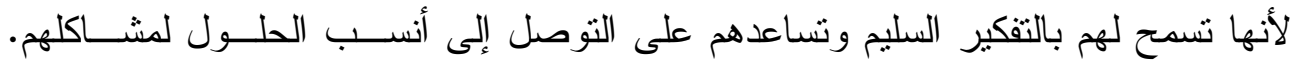

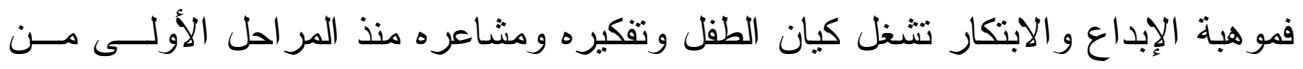

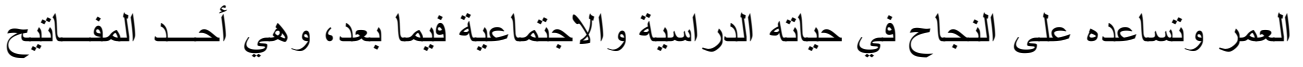

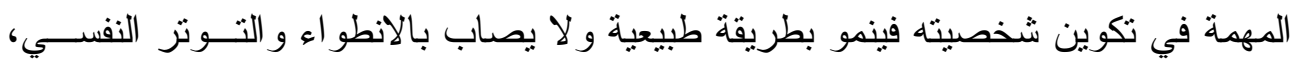

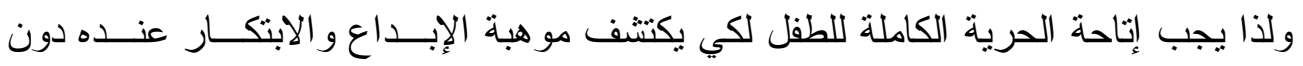

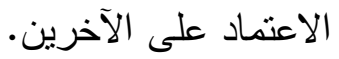

فقد ثبت أن بعض الأجززة و الأدوات تشاعد على الابتكار أكثر مــن أي نــوع مــن

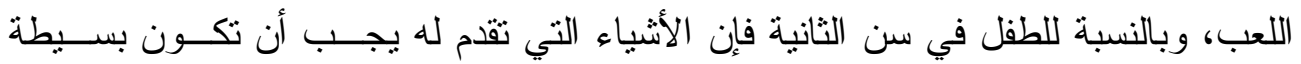

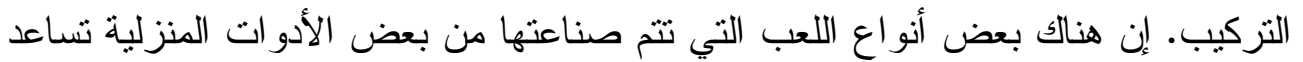

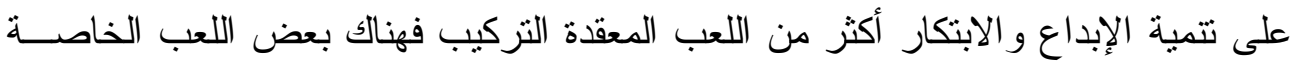

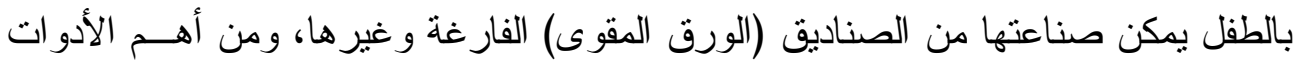

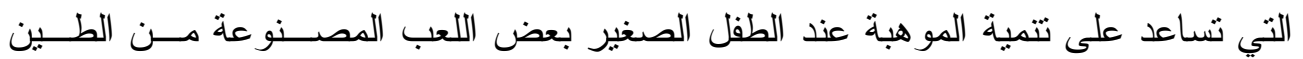

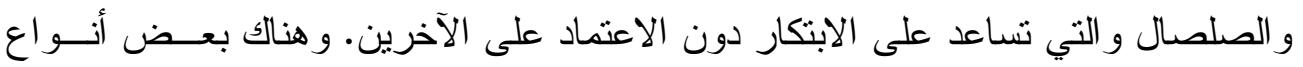

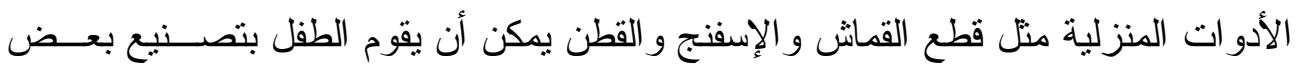

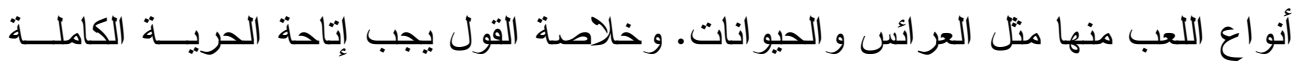
للطفل في ابتكار تكوين الأشياء التي يريدها من هذه الخامات.

\section{تنمية التفكير الابداعي: - n}

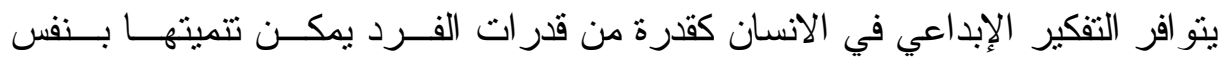

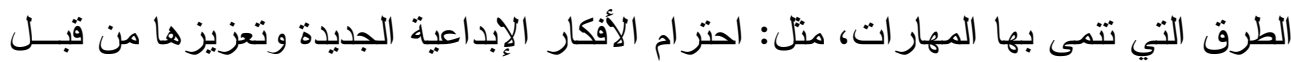

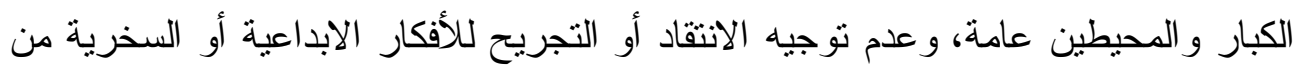

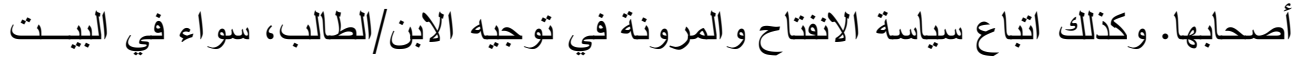

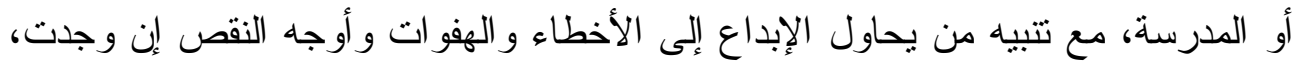

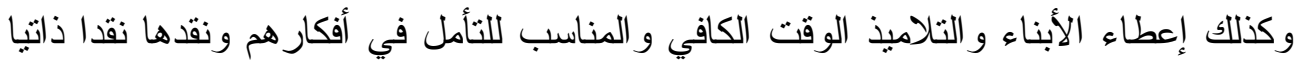
وتطوير ها. 
و هناك محورين أساسيين لتتمية التقكير الابداعي هما:

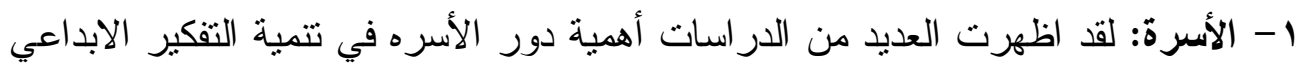

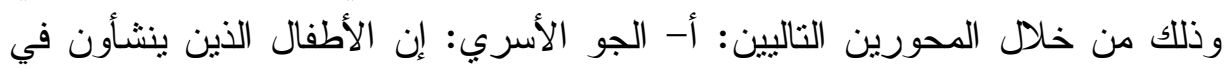

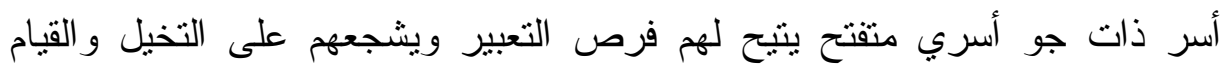

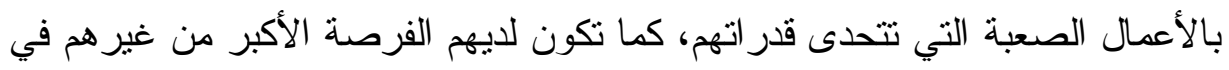

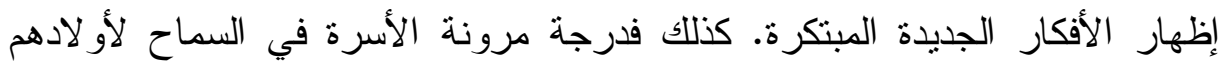

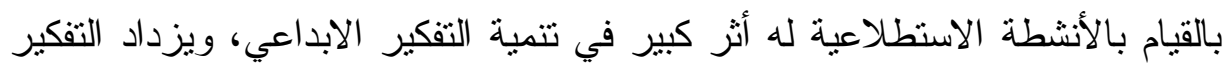

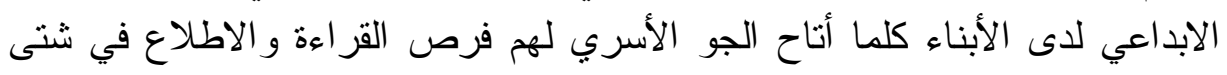

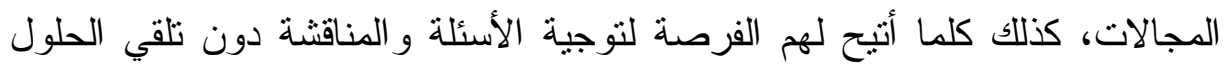

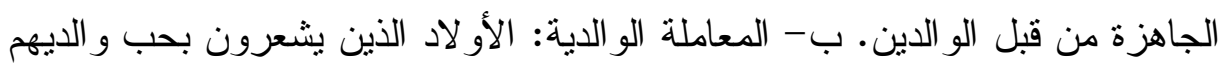

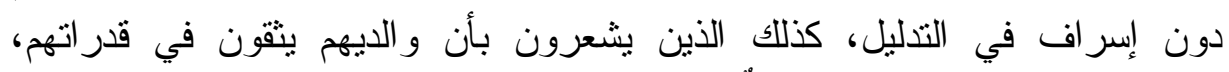

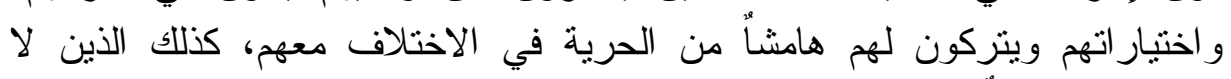

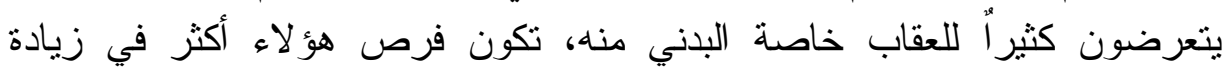

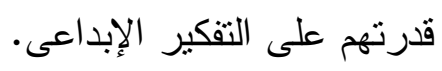

r- المدرسة: يأني دور المدرسة ليغذي ويدعم ما بدأته الأسرة و البيئة المدرسية تكون

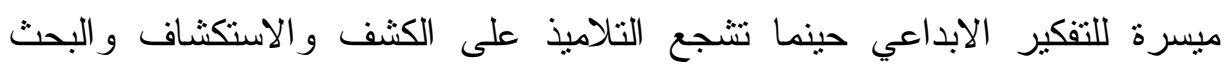

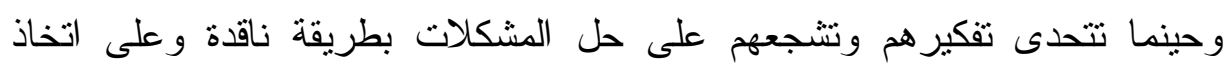

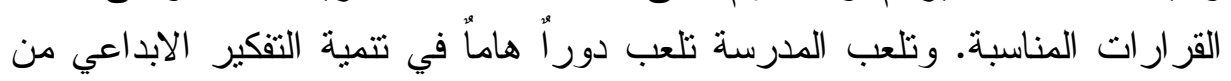

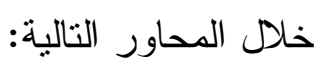
أ -الفصل المدرسي: إن مجموعة المواقف والخبرات العقلية والانفعالية والاجتماعية

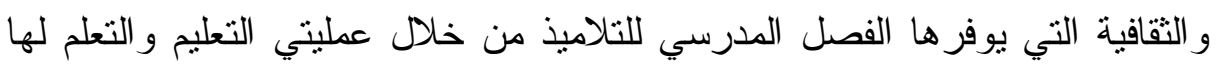
بالغ الأثز على استثارة وتتجيع وتتمية التقكير الابداعي لديهر.

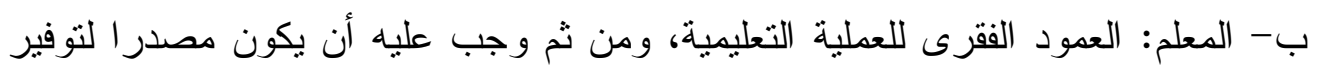

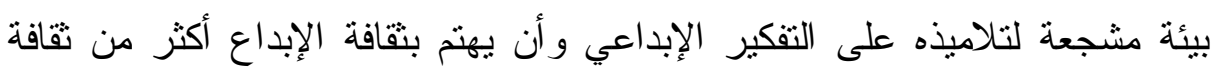

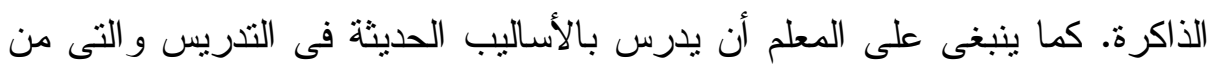

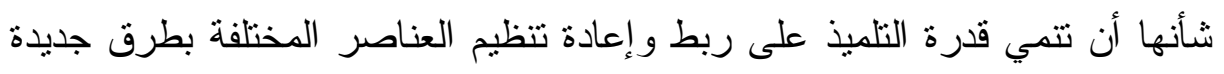

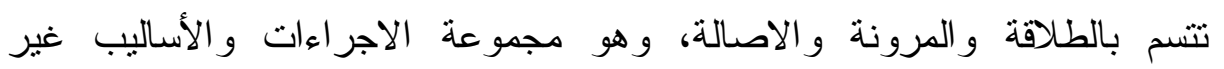

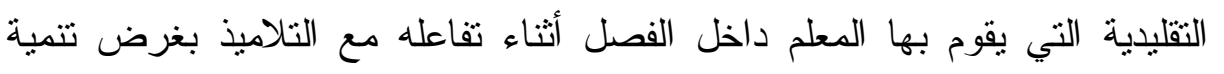

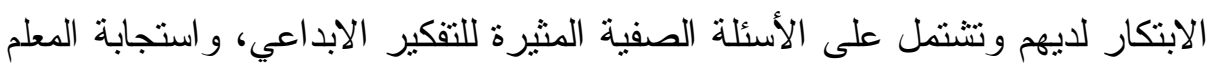

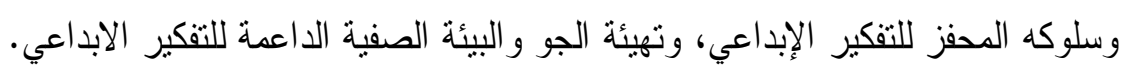


يجب أن يكون مدير المدرسة له الخبرات والخديائصالتى تمكنه من توفير مناخا

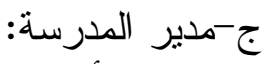

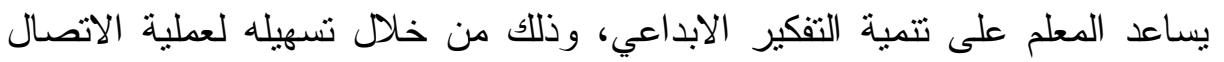

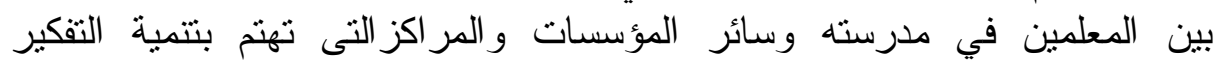
الابداعي، وأن يكون ذا أفق و اسع قادر ا على حل المشكلات و التعامل مع المو اقف المبن الصعبة.

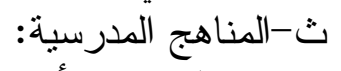

من المفترض أن يحتوب المنهج على أنشطة ابتكارية تساعد التلاميذ علي تتمية التفكير

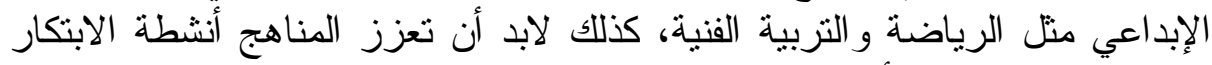

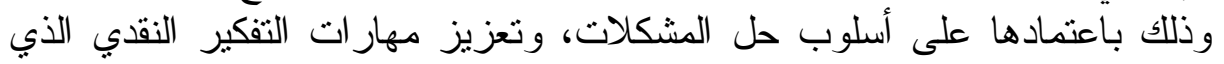
من شأنه أن يساعد على تنمية التفكير الابداعي.

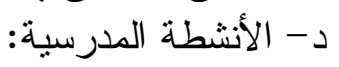

أنشطة الفصل لابد أن تكون متتوعة ومتتابعة وأن تحتوي على مهار ات شخصية

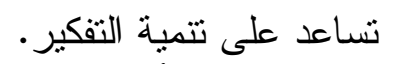

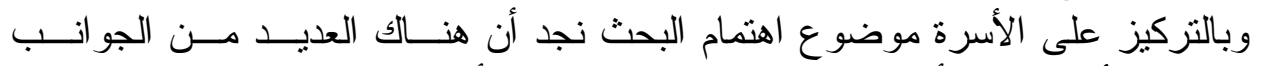
المناخية في الأسرة يمكن أن تساعد على على تتمية الإبداع من الهن أهمها:

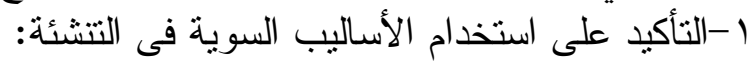

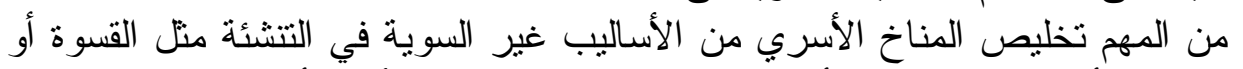

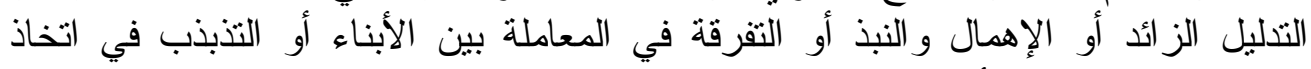

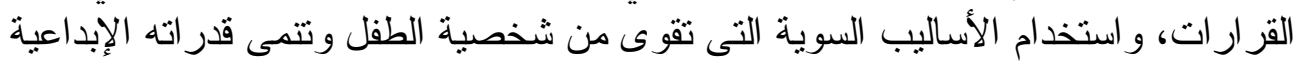
r- نوفير بيئة للعب:

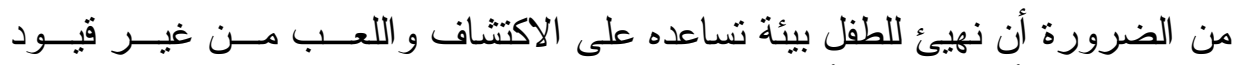

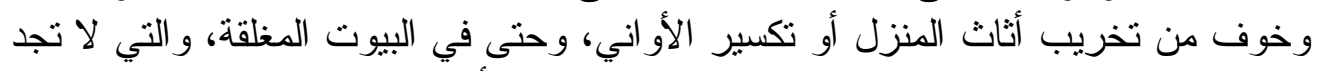

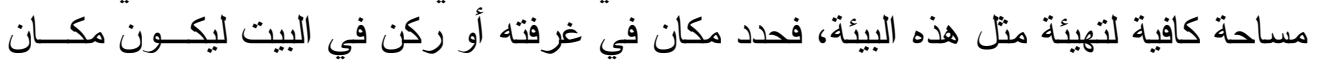
لعبه و اكتشافاته.

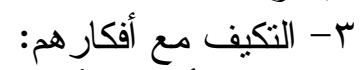

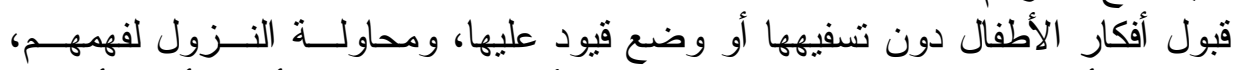

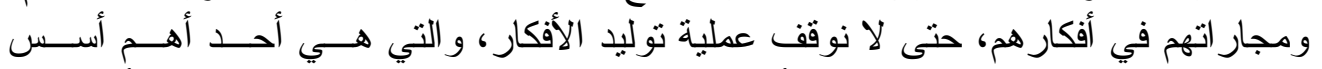

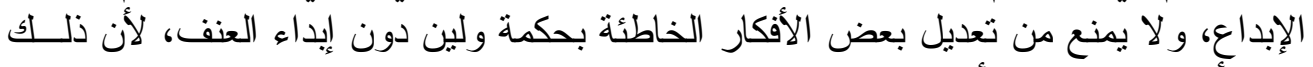

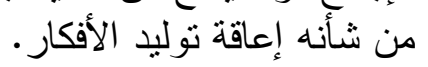

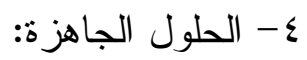

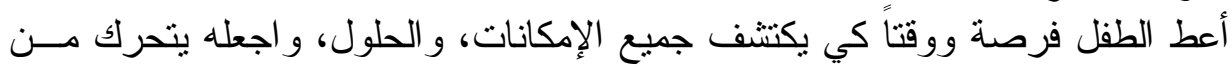

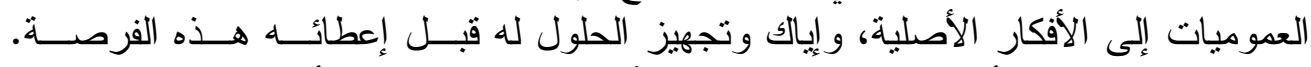

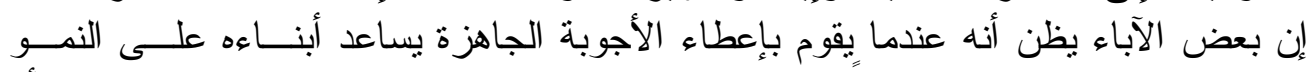

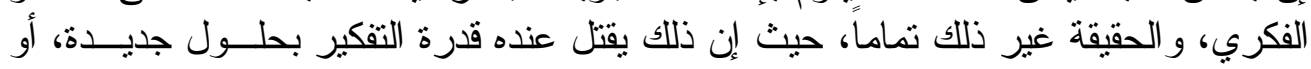
حتى محاولة التفكير بحلول. 
ركز على طرق التفكير أكثر من التزكيز على النتائج، فليس مهاً أن يكسب المسابقة،

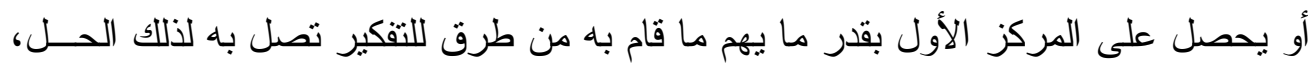

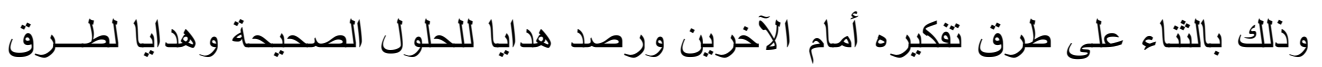
التفكير السليم.

7- إعطاء الفرصة للمغامرة:

إعطاء فرصة للطفل للتحدي و المغامرة عن طريق بعض الألعاب و المنافسة بينه وبين

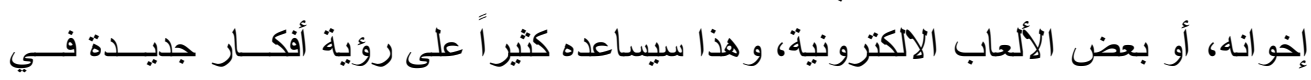

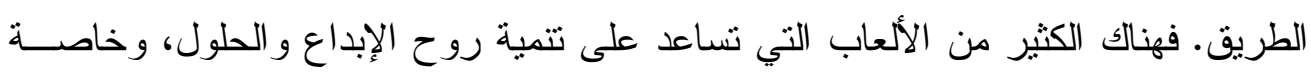

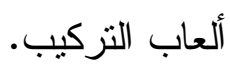

V V-المناقشة و الحو ار الفعال و التفاعل معهم: أ- التحدث مع الأطفال ساعة كاملة يومياً على أقل تقدير عن أنشطتهم اليومية، وكيفية

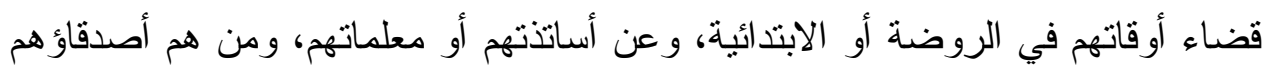

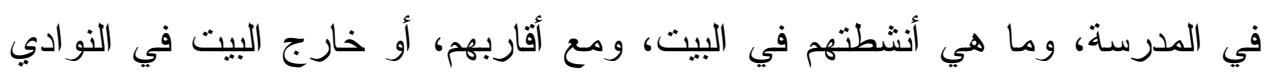

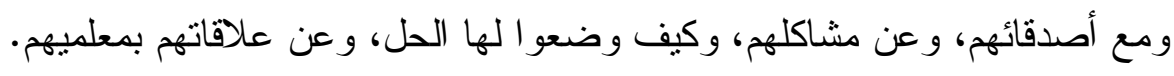

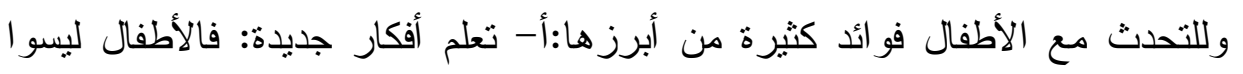

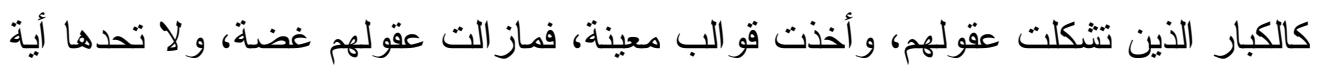

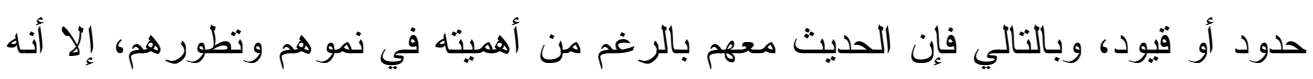

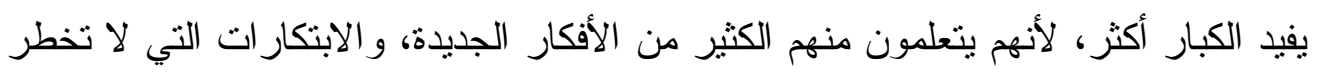

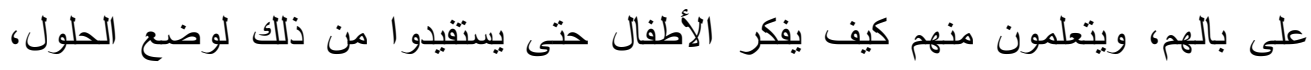

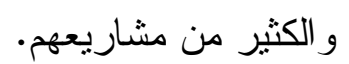

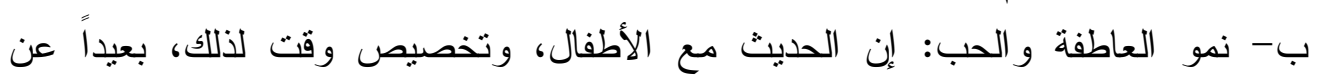

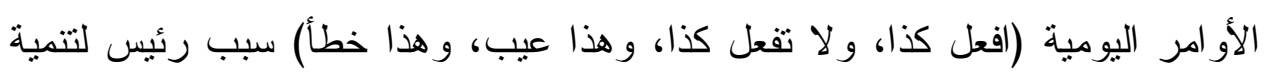

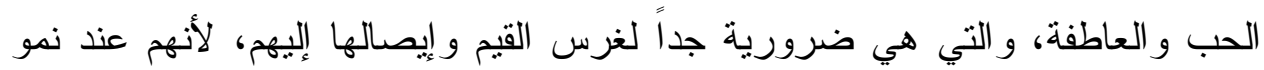

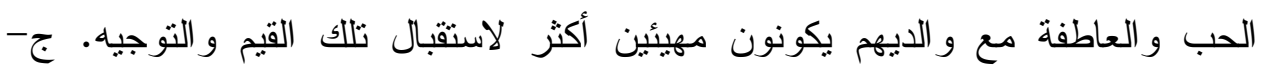

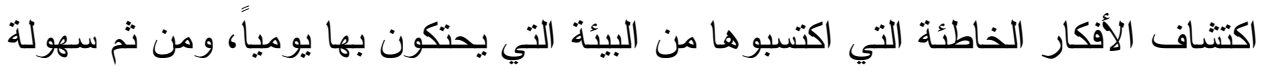

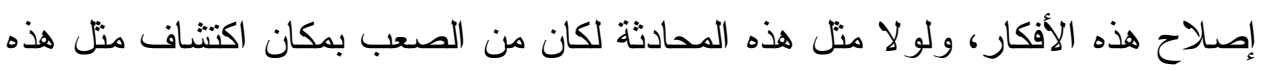
الأفكار الخاطئة. 
1- التخلى عن التفكير التقليدى:

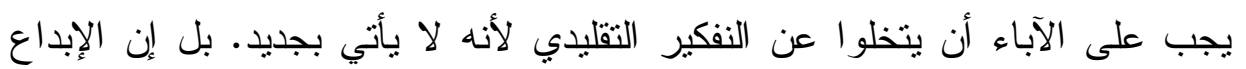

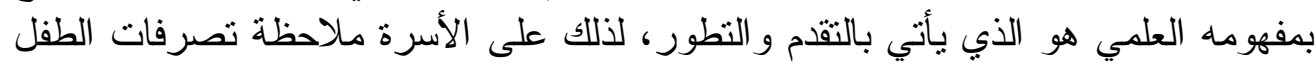

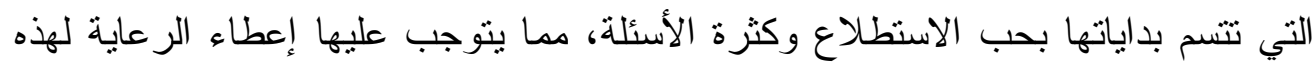

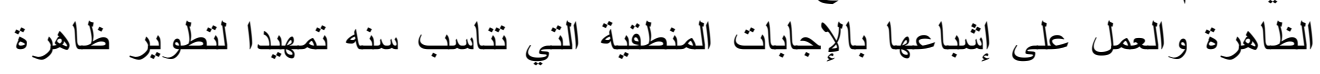

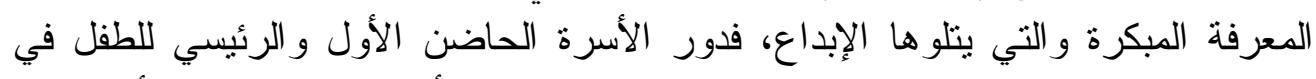

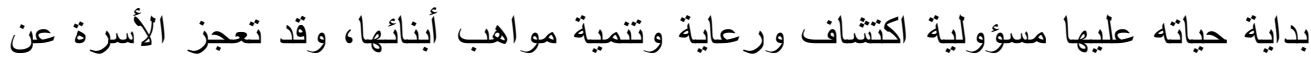

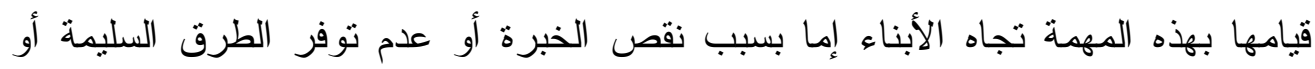

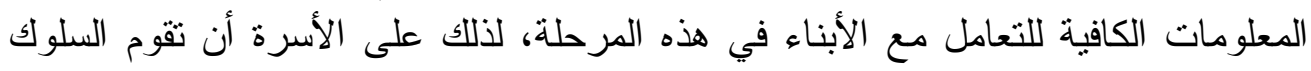

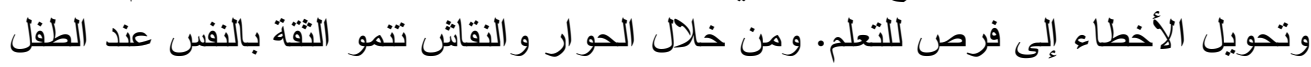

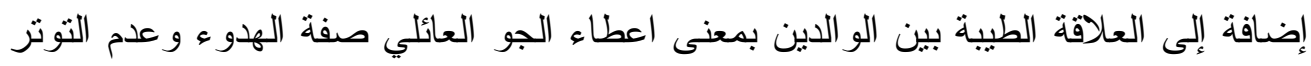

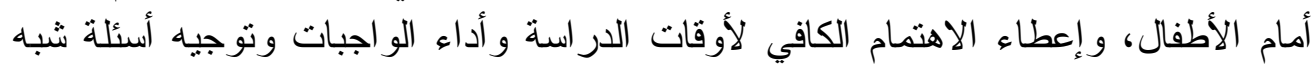

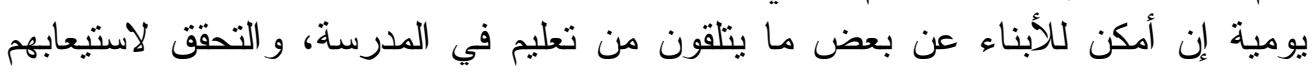

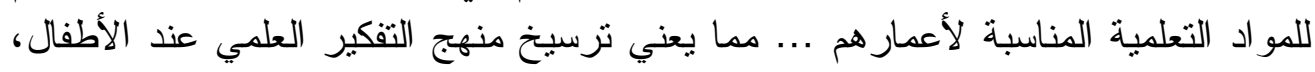

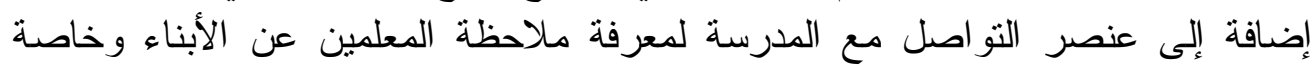

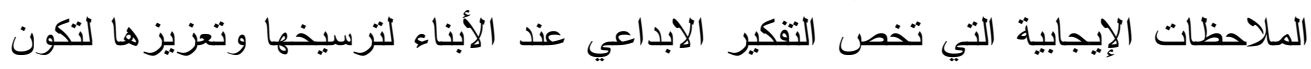

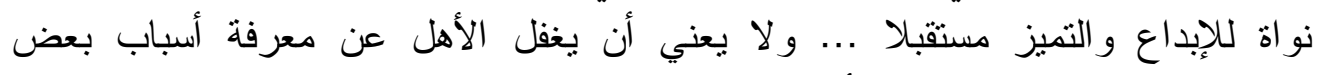

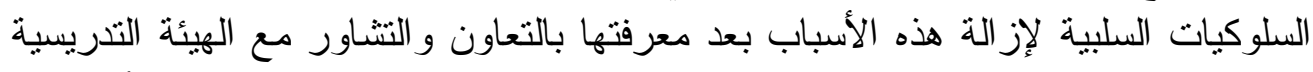

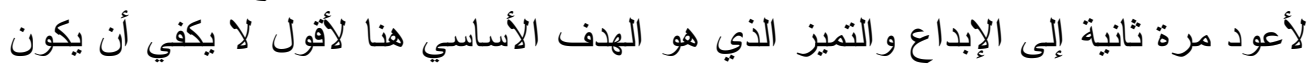

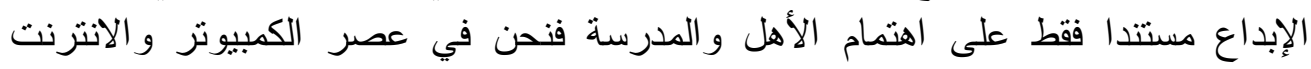

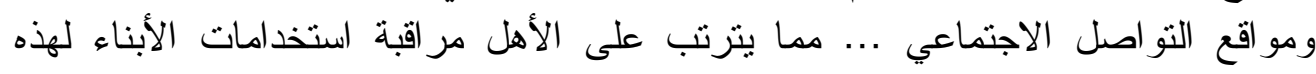

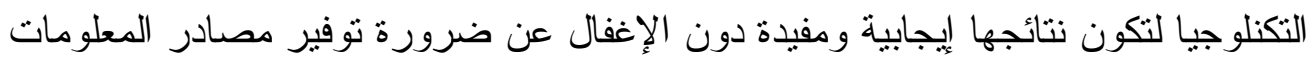

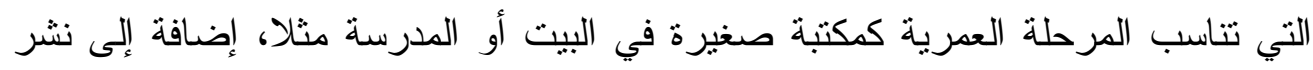

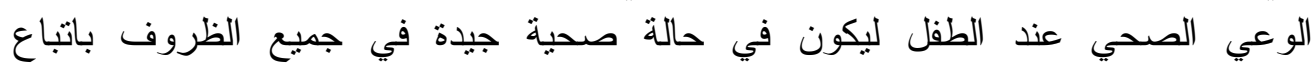
السلوكيات الصحية الجيدة. 9-تتمية حب الاستطلاع و الاكتثاف و القر اءة وحب المعرفة لدى الطفل.

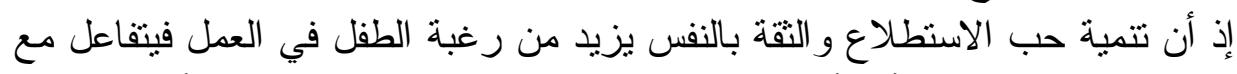

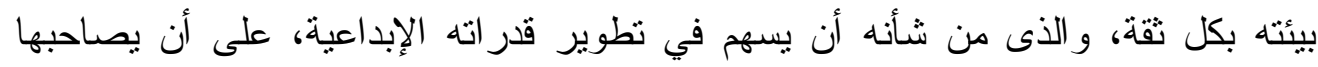

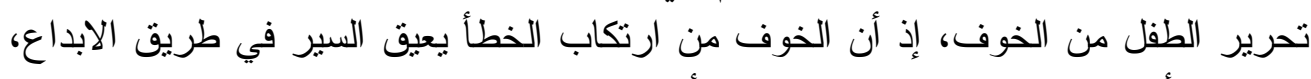

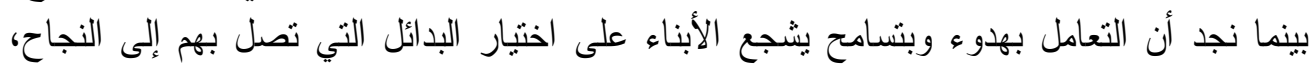

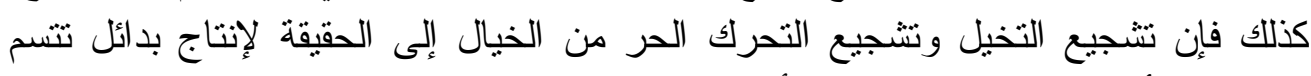

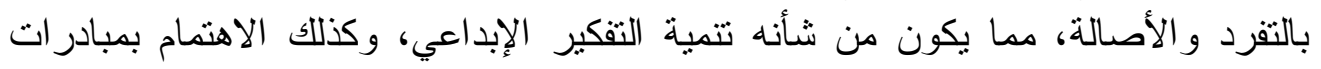

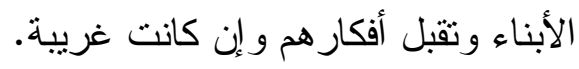




$$
\text { • إممارسة الهو ايةة: }
$$

من المهم أن يمارس الطفل هو ايته وميوله خاصة في فترات العطل و الإجازات، فإن ذلك أدعى للتقوق فيها و الإبداع، مع صقل الموهبة والارتقاء بها من خلا الممارسة العملية.

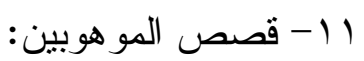

من وسائل التعزيز و التحفيز: ذكر قصص السابقين من الموهوبين و المتفوقين، و الأسباب التي أوصلتهم إلى العلياء و القِمَم، وتحبيب شخصياتهم إلى الطفل ليتَّذهم مثنلاً

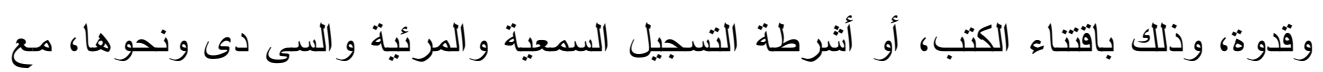

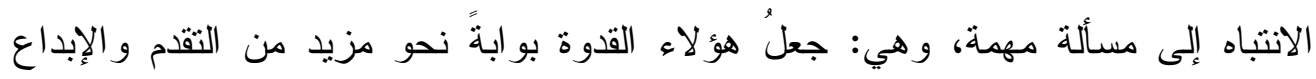

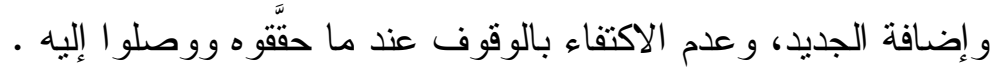

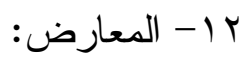

من وسائل التعزيز و التشجيع: الاحتفاءُ بالطفل المبدع وبنتاجه، وذللك بعرض ما يبدعه

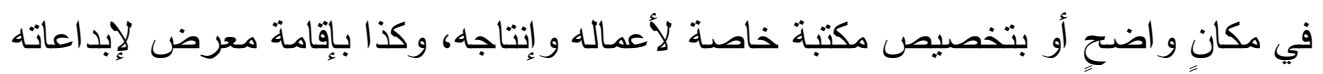
يُدعى إليه الأقرباء و الأصدقاء في منزل الطفل، أو في منزل الأسرة الكبيرة، أو في قاعة المدرسة.

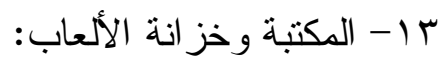
الحرص على اقتناء الكتب المفيدة و القصص النافعة ذات الطابع الابتكاري، المرفق

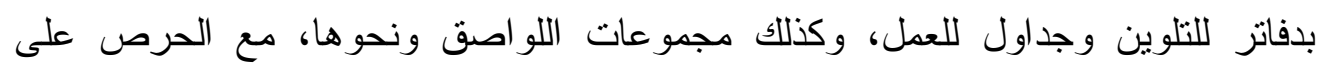

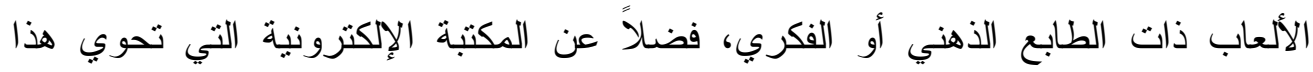

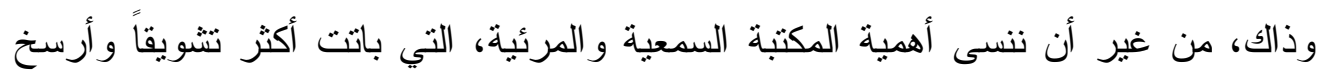
فائدة من غير ها. 


\section{توصيات و إرشادات لتشجيع الإبداع في البيئة الأسرية:}

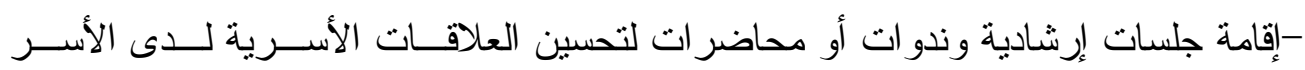
وتوعيتها بأساليب المعاملة الأسرية التي قد تبين أن لها دور في تشجيع إبداع الأبناء.

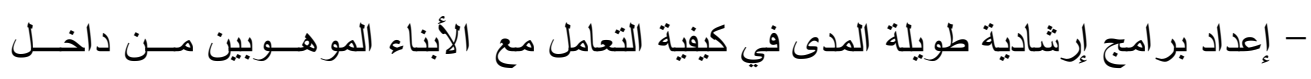
الأسرة الو احدة.

- مساعدة المختصين في مجال رعاية المو هوبين للتخطيط لبــر امج الموهـوبين و أســاليب اكتشافهر.

- توجيه الآباء و المربين بألا يفرضوا آراءهم الفنية على تعبير ات الأطفال، حتى ينسنى لهم

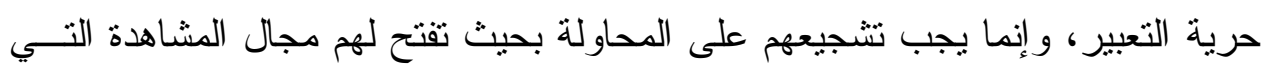

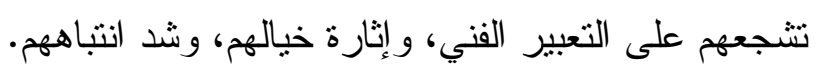

- نتجيع الفروق الفردية في الميول و القدرات لدى الأطفال و العمل على تدعيمها. - تجنب النقد و السخرية لأوجه القصور ، لأن ذلك يؤثز سلباً على التقكير الإبداعي.

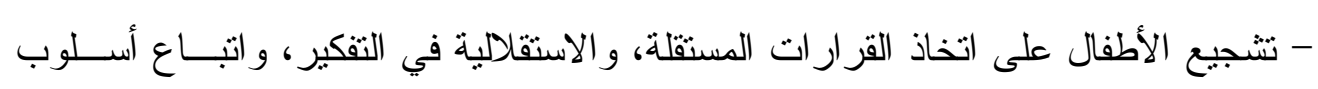
الحو ار و المناقشة، وتتجيعه على حرية الاختيار .

- إثباع الحاجات النفسية للطفل. - استخدام أساليب المعاملة السوية و الابتعاد عن الأساليب غير السوية منل: الابتعـاد عـن

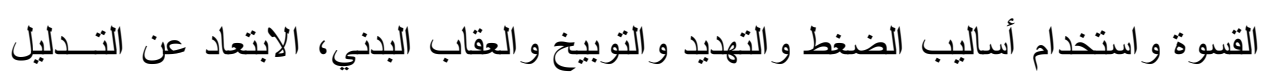

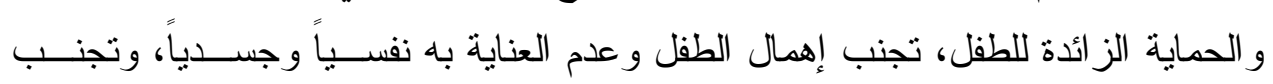
التقرقة في المعاملة بين الأبناء، والابتعاد عن تذبذب سلوك الهمال الآباء تجاه الطفل. - ضرورة تعريض الطفل لخبرات متتوعة، وإتاحة الفرص له لإنتـــاج الأفكــار الجديـــة، و الاستجابات المتتو عة للمثير ات و الخبر ات التي توجد حول ولتئل الطفل. - تشجيع حب الاسنطلاع عند الطفل، وحثه على اكتشاف الأفكار بنفسه لتوليد الثقة بالذات . 


\section{المراجع}

\section{أولاً: المراجع العربية}

1-أحمد جبر ( . . †). نشرة مضامين الدراسات التربوية حول الإبداع في فلسطين، جامعة القدس

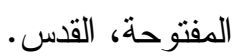

Y-جمال محمد الخطيب(991)(19). مقدمة فى الإعاقة السمعية. الأردن،عمان: دار الفكر للطباعة

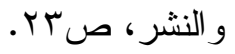

r-جميل الطهر اوي(T . . r). الأستاذ الجامعي والإبداع. بحث مقدم في اليوم الدراسي الثالث

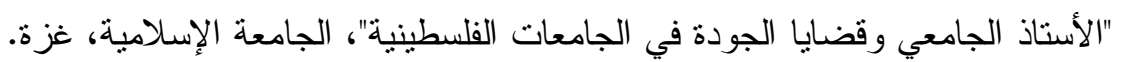

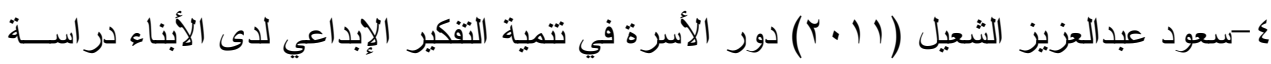

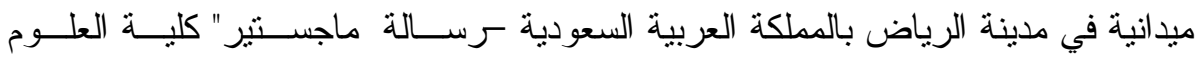
الاجتماعية. جامعة الإمام محمد بن سعود الإسلامية- المملكة العربية السعودية.

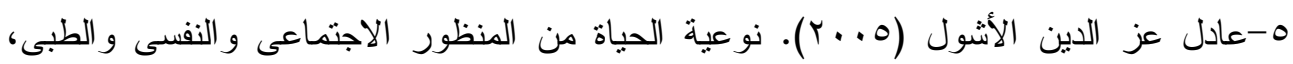

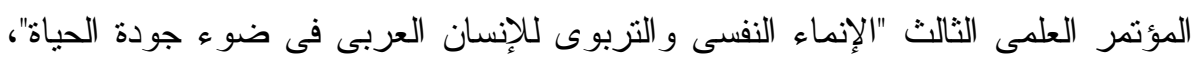
كلية التربية، جامعة الزقازيق، 10 -17 1 مارس.

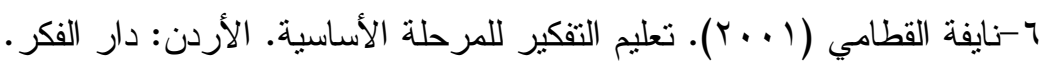

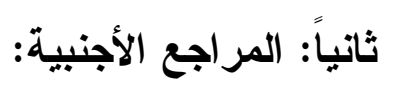

7-Andrews,F.M.\&Withey,S.B.(1976). Social indicators of well-being: Americans` perception of life quality .New York: Plenum.

8-Benjamin Shaw;Kraus Neal;Chatters,Lindao(2004). Emotional support from parents early in life, Aging, and health. Psychology and Aging, Vol. 19, No. 1,4-12.

9-Bronzaft,Arline,L.(1996).Top of the class: Guiding children along the smart path to happiness. Creativity Research.

10-Brown,I.\&Brown,R.(2006).Individual and family quality of life. Mukibaum Treatment Centers for Children and Adults with complex disabilities.

11-Brown,Roy(2009).Individual and family quality of life: Issues of aging and intellectual disability. Hong Kong Joint Council for people with Disabilities /Hong Kong Council of Social Service. 
12-Daniel,T.;Shek\&Lee,T.Y.(2007).Family life quality and emotional quality of life in chine adolescents with and without economic disadvantage .Social Indicators Research,80,pp.393-410.

13-Davis, Phyllis,Ann.(2009).Quality of life of people with disabilities: Stories of successful adults. Ashland University, ProQuest, UMI Dissertations Publishing. 3357567.

14- Denise , J. P. ( 2002 ) . A qualitative analysis of the conceptualization and domains of family quality of life for families of children with disabilities , PhD. Thesis, Department of Special Education, Faculty of the Graduate School, University of Kansas, 14- 15.

15-Dennis, R. E., Williams, W., Giangreco, M. F., \& Cloninger, C. J. (1993). Quality of life as context for planning and evaluation of services for people with disabilities. Exceptional Children. 59(6). 499-512.

16-Downing ,P. James (1997). Creative Teaching, Teacher Ideas Press, Engle Wood, Colorado, USA .

17-Erikson,E.H.(1964).Childhood and society. New York: Penguin Books.

18Isaascs,B.;Brown,I.;Brown,R.;Baum,N.;Myerscough,T.;Neikrug,S.;Roth, D.; Shearer, J.\& Wang, M.(2007).The internal family quality of life project: Goals and practice in Intellectual Disabilities, Vol.4,N., 3,PP. 177-185.Sep.

19-Lonescu,Aurrelia(1998).Clinical phenomena of family psychopathology: Diagnostic reference points from the perspectives of family psychotherapy. Journal of Revue-Roumain Des Sciences Socials Series De Psycholoyie, Vol. 29(2),PP.147-156.

20-Mytko, J. J., \& Knight, S. J. (1999). Body, mind and spirit: Towards the integration of religiosity and spirituality in cancer quality of life research. Psycho-Oncology, 8, 439-450.

21-Park,J.Turnbull,A.\&Turnbull,H.,R.(2002).Impacts of poverty on quality of life in families of children with disabilities. Exceptional Children,68(2),PP.151-170.

22Park,J.;Hoffman,L.;Marquis,J.;Turnbull,A.;Poston,D.;Mannan,H.;Weny, M. \&Nelson, L.(2003).Toward assessing family outcomes of service delivery: validation of family quality of life survery. Journal of Intellectual Disability Resarch,47(415),367-384. 
23-Paterson,G.\&Sanson,A.(1999).The association of behavioral adjustment to temperament, parenting and family characteristics among 5 yearold children N. Social Development,8,293-309.

24-Poston,D.;Turnbull,A.;Park,J.;Mannan,H.;Marquis,J.\&Wang,M.(2008).F amily quality of life outcomes: A qualitative inquiry launching a long-term research program. Mental Retardation,41(5),313-328.

25-Roberts,R.N.;Innocenti,M.S.\&Goetz,L.P.(1999).Emerging issues from state level evaluations of early intervention programs. Journal of Early Intervenation,22(2),152-163.

26-Turnbull,A.;Marquis,J.;Hoffman,L.;Poston,D.;Summers,J.;Mannan,H.\& Wang, M. (2005).A new tool for assessing family outcomes: Psychometric evaluation of the Beach Center Family Quality of life scale. Journal of Marriage and Family,68,1069-1083.

27-Turnbull,A.;Summers,J.;Lee,S.;Kyzar,K.(2007).Conceptualization and measurement of family outcomes associated with families of individuals with intellectual disabilities. Mental Retardation and Developmental Disabilities Research Reviews,B.,PP.346-356.

28-Verdugo,M.A.;Cordoba,L.\&Gomez,J.(2005). Spanish adaptation and validation of the family quality of life survey. Journal of Intellectual Disability Research,Vol.49,Part 10,PP.794-798 ,Oct.

29-Wang Mian\& Brown Roy (2009). Family quality of life: for policy and social service provisions to support families of children with disabilities. Journal of Family Social Work,Vol.12,Issue2,April,PP.144-167. 